\title{
Peran Badan Wakaf Indonesia Pasca Terbitnya Undang-Undang Nomor 41 Tahun 2004 Tentang Wakaf*
}

\author{
Mohamad Hendrik, ${ }^{1}$ Mufidah Mufidah ${ }^{2}$ \\ Program Studi Hukum Tatanegara (Siyasah) \\ Fakultas Syariah, Institut Agama Islam Az-Zaytun indonesia \\ d. \\ $10.15408 /$ sjsbs.v6i5.20830
}

\begin{abstract}
Law Number 41 of 2004 concerning Waqf establishes a new paradigm on Waqf governance in Indonesia. Initially, waqf was managed in a simple and kinship manner because it was a teaching in Islamic law that grew to become part of the traditions that live in society, which then transformed into institutional governance, which has credibility, professionalism, and efficiency. This study uses a library research method with a normative and historical juridical approach. Using primary legal sources of legislation Number 41 of 2004 concerning Waqf is strengthened by secondary legal sources from books, legal journals and the internet as well as legal doctrines. From this study, it is concluded that the Indonesian Waqf Board has a role in building governance of the implementation of Waqf in Indonesia both in administering and managing nationally, namely fostering nazhirs.
\end{abstract}

Keywords: Waqf; Indonesian Waqf Board; Law Number 41 Year 2004 concerning Waqf

\begin{abstract}
Abstrak
Undang-Undang Nomor 41 Tahun 2004 tentang Wakaf membangun paradigma baru tentang tata kelola Wakaf di Indonesia. Wakaf yang semula dikelola dengan cara sederhana dan kekeluargaan karena merupakan ajaran dalam hukum Islam yang tumbuh akhirnya menjadi bagian dari tradisi yang hidup dalam masyarakat, yang kemudian bertransformasi dalam bentuk tata kelola lembaga, yang memiliki kredibelitas, profesionalitas, dan efesien. Penelitian ini menggunakan metode library research dengan pendekatan yuridis normatif dan historis. Menggunakan sumber hukum primer peraturan perundang-undangan Nomor 41 Tahun 2004 tentang Wakaf diperkuat dengan sumber hukum sekunder dari buku, jurnal hukum dan internet serta doktrin-doktrin hukum. Dari penelitian ini, disimpulkan bahwa Badan Wakaf Indonesia memiliki peranan dalam membangun tata kelola pelaksanaan Wakaf di Indonesia baik dalam menyelenggarakan administrasi maupun pengelolaan secara nasional yakni membina para nazhir.
\end{abstract}

Kata Kunci: Wakaf; Badan Wakaf Indonesia; Undang-Undang Nomor 41 Tahun 2004 Tentang Wakaf

${ }^{*}$ Diterima: 13 Mei 2019, Revisi: 15 Juni 2019, Diterima 17 Juli 2019.

${ }^{1}$ Mohamad Hendrik adalah Peneliti pada Program studi hukum tatanegara (siyasah) Fakultas syariah, institut agama islam az-zaytun Indonesia.

${ }^{2}$ Mufidah Mufidah adalah dosen Program studi hukum tatanegara (siyasah) Fakultas syariah, institut agama islam az-zaytun indonesia. 


\section{A. PENDAHULUAN}

Wakaf adalah salah satu ibadah maaliyah umat Islam yang memiliki dimensi ibadah sekaligus juga nilai sosial. Pelaksanaan Wakaf di dalam masyarakat Indonesia hidup sebagai sendi juga instrumen perekonomian untuk kepentingan sosial. Bahkan eksistensi Wakaf sebagai instrumen perekonomian telah ada sejak zaman kolonialisme, oleh sebab itu Wakaf bukanlah suatu hal yang baru bagi bangsa Indonesia.

Pada masa kolonialisme Wakaf hidup sebagai ketentuan hukum adat yang tidak tertulis dalam hal pelaksanaannya. Wakaf dilaksanakan secara natural oleh masyarakat Islam sebagai nilai-nilai keagamaan dan bentuk kepatuhan beragaman saja, sehingga masyarakat tidak membutuhkan legitimasi pemerintah dalam hal pengaturannya. Namun kemudian seiring dengan politik hukum pada masa kolonialisme juga, pelaksanaan hukum Islam dibatasi dengan munculnya teori receptie in Complexu yang dipelopori oleh Christian Snouck Hurgronje, sehingga kemudian pelaksanaan Wakaf yang telah menjadi adat dalam masyarakat mengalami pembatasan dalam pelaksanaannya. Dalam teori tersebut Snouck Hurgronye berusaha melemahkan ajaran Islam yang hidup di masyarakat. Menurut teori receptie in Complexu bahwa hukum Islam tidak secara otomatis berlaku bagi orang Islam sebelum diterima oleh adat.

Upaya politik yang dilakukan oleh Belanda dalam membatasi eksistensi hukum Islam tidak secara otomtis menghambat pelaksanaan Wakaf pada masa itu, mengingat kesadaran masyarakat dalam melaksanakan Wakaf telah hidup menjadi natural law dalam masyarakat, bahkan dapat dikatakan sebagai sebuah tradisi yang sangat melekat dengan adat. Kenyataan tersebut memaksa pemerintah kolonial untuk menerbitkan peraturan tentang pelaksanaan Wakaf dalam bentuk surat edaran dengan tujuan politik Belanda pada saat itu yakni mengawasi gerak-gerik hukum Islam sehingga tidak menjadi sebuah gerakan yang akan membahayakan pemerintah Belanda. ${ }^{3}$

Terlepas dari berbagai strategi politik pemerintah Belanda dalam membatasi hukum Islam tersebut, diketahui juga bahwa pengaturan dalam surat edaran yang dikeluarkan oleh pemerintah Belanda terkait pelaksanaan Wakaf adalah untuk keperluan administratif sebagai salah satu syarat perizinan agar tidak bertentangan dengan kepentingan umum dan pelanggaran terhadap peraturan-peraturan umum yang dibuat oleh pemerintah Belanda.

Sebagaimana yang telah disampaikan dalam paragraf sebelumnya, bahwa surat edaran Wakaf hanya pola pengaturan secara administrarti sehingga pada masa itu perwakafan tidak diatur secara tuntas dalam peraturan perundang-undangan yang ada. Bahkan dapat dikatakan pelaksanaan Wakaf mengalir apa adanya sebagaimana kehidupan masyarakat yang identik dengan tradisi dan adat. Wakaf kurang memperoleh penanganan secara sungguh-sungguh baik ditinjau dari pemberian motivasi maupun pengelolaannya. Akibatnya terjadi penyimpangan atas pengelolaan

${ }^{3}$ Sukanto, 1981, Meninjau Hukum Adat Indonesia Suatu Pengantar untuk mempelajari Hukum Adat, Jakarta: Rajawali Press, h.51. 
Wakaf yang tidak sesuai dengan tujuan Wakaf serta fungsinya sebagiamana syariat Islam. Tidak adanya ketertiban pendataan mengakibatkan benda Wakaf yang tidak terindentifikasi, tidak terurus bahkan mengakibatkan benda Wakaf tersebut justru dimanfaatkan oleh pihak yang tidak bertanggung jawab untuk diperjualbelikan. ${ }^{4}$

Dalam sejarah perkembangan Islam di Indonesia yang religius, pemahaman tentang Wakaf masyarakat tidak terlepas dari proses historis awal masuknya Islam di Nusantara berikut dengan perkembangannya. Namun setelah lebih dari setengah abad Indonesia merdeka, masalah kesejahteraan dan kualitas sumber daya manusia merupakan suatu problem sosial yang sulit teratasi. Oleh karenanya kemiskinan yang merupakan masalah universal dalam bangsa ini akan dapat diringankan dengan adanya Wakaf. Terlebih saat ini Wakaf telah mengalami perkembangan dalam pelaksanaannya dalam bentuk produktif. Sehingga apabila Wakaf dapat dikelola dengan bentuk manajemen lembaga yang profesional, niscaya upaya pengetasan kemiskinan di Indonesia akan lebih cepat terselesaikan.

Bersama dengan harapan tersebut maka tentu tata kelola Wakaf menuju profesionalisme wajib memperoleh perhatian baik dari pemerintah maupun masyarakat serta umat Islam secara bersama-sama. Misalnya saja berkaitan dengan pengelolaan manajemen maka tekhnik fundraising juga akan memberikan potensi maksimal dalam penghimpunan kesadaran masyarakat dalam menunaikan Wakafnya. Dengan demikian peningkatan produktivitas Wakaf akan sangat menguntungkan pemerintah. ${ }^{5}$

Lahirnya berbagai peraturan perundang-undangan Nomor 41 Tahun 2004 (selanjutnya akan disebut dengan UU No. 41/2004) merubah paradigma tentang tata kelola Wakaf menjadi profesional. Sepanjang sejarah bangsa Indonesia UU No. 41/ 2004 Tentang Wakaf bukanlah peraturan pertama yang diterbitkan pemerintah dalam mengatur tata kelola Wakaf. Peraturan pertama tentang Wakaf sepanjang kemerdekaan diterbitkan untuk pertama kalinya dalam Peraturan Pemerintah Nomor 28 Tahun 1977 Tentang Perwakafan Tanah Milik yang memuat peraturan terkait perwakafan tanah saja dan belum mencakup harta perwakafan lainnya sebagaimana hasil dari pelaksanaan Wakaf produktif.

Pelaksanaan Wakaf tanah sendiri diatur pemerintah setelah banyak terjadi permasalahan serta aduan sengketa terhadap tanah Wakaf dalam masyarakat. Fenomena tersebut terjadi karena peraturan perwakafan yang ada pada saat itu kurang memadai, sehingga pemerintah pun sulit menertibkan tanah Wakaf yang jumlahnya cukup banyak bahkan kendala tersebut juga dirasakan masyarakat dan lembaga pengelola tanah Wakaf.

Pada nyatanya pelaksanaan Wakaf di Indonesia hanya sebatas penyerahan benda atau barang yang dapat digunakan oleh umat secara bersama-sama, misalkan saja berupa masjid, mushalla, madrasah sekolah, makam atau juga rumah untuk Media, h.11.

4 Abdul Anshori Ghofar. 2005. Hukum dan Praktik Perwakafan Di Indonesia. Yogyakarta: Pilar ${ }^{5} \mathrm{Ni}$ 'matul Huda. 2005. Hukum Tata Negara Indonesia. Jakarta: Raja Grafindo. 
pemeliharaan anak yatim piatu. Pelaksanaan Wakaf secara konvensional ini tidak dapat membangun sebuah instrumen dalam segi sosial dan ekonomis untuk menyelesaikan permasalahan umat, terlebih pemahaman Nadhir, Wakif juga masyarakat secara luas terbatas terhadap Wakaf produktif sehingga pelaksanaan Wakaf hanya dimaknai sebatas ikrar Wakif seperti saja tanpa memaksimalkan manfaat Wakaf tersebut. ${ }^{6}$

Wakaf yang dilaksanakan secara tradisional berjalan tertib dan efisien dengan ketentuan yang sangat terbatas, sehingga dalam berbagai kasus sebagaimana dikemukakan di atas harta benda Wakaf juga tidak terpelihara sebagaimana mestinya. Keadaan demikian itu, bukan hanya karena kelalaian atau ketidakmampuan Nadhir dalam mengelola dan mengembangkan harta benda Wakaf tetapi karena juga sikap masyarakat yang tidak peduli atau belum memahami status harta benda Wakaf yang seharusnya dilindungi untuk kesejahteran umum sesuai dengan tujuan, fungsi, dan peruntukan Wakaf.

Perwakafan tidak mengatur secara tegas dan tuntas terkait pengalihan hak, penjualan tanah Wakaf serta pendataan tanah Wakaf, hal ini menjadi salah satu kekurangan pelaksanaan Wakaf. Kelemahan lainnya sebelum adanya Badan Wakaf Indonesia (BWI) dan UU Nomor 41 Tahun 2004 yaitu pelaksanaan Wakaf yang menimbulkan persengketaan yang terjadi karena adanya perubahan peruntukkan Wakaf, seperti perubahan tanah Wakaf menjadi milik perseorangan atau juga peruntukkan benda yang semula untuk masjid yang kemudian oleh Nadhir dimanfaatkan untuk keperluan lain tanpa adanya pemberitahuan dan musyawarah dengan pihak yang berkepentingan (dalam hal ini adalah Wakif atau keluarga). Dalam hal lain persengketaan yang sering timbul adalah kasus dimana apabila setelah Wakif meninggal dunia, sebagian ahli warisnya menolak dan tidak mengakui bahwa tanahnya tersebut telah diwakafkan.

Pada fase ini pengelolaan Wakaf di Indonesia jauh ketinggalan dari negara Islam lainnya yang sudah mengarah pada Wakaf produktif. Seperti yang dilakukan di Mesir sejak tahun 1971, pengelolaan Wakaf mengalami kemajuan. Pengelolaan Wakaf di negeri ini sudah mengarah kepada pemberdayaan ekonomi. Pihak pengelola Wakaf melakukan kerja sama dengan bank Islam, pengusaha, developer. Kementerian Perwakafan (Wizarah al Awqaf) di negeri ini membangun tanah-tanah kosong yang dikelola secara produktif dengan mendirikan lembaga-lembaga perekonomian, ataupun dalam bentuk pembelian saham di perusahaan-perusahaan. ${ }^{7}$

Indonesia sebagai mayoritas muslim terbesar dalam mengelola aset Wakaf di masyarakat bisa lebih dari apa yang dilakukan Mesir, hanya saja keberadaan nazhir yang belum profesional, regulasi perwakafan juga pemahaman masyarakat terkait pelaksanaan Wakaf menjadi penyebab Wakaf belum bisa dikelola secara optimal. Untuk menciptakan itu semua memerlukan kerjasama antara institusi pemerintah,

\footnotetext{
${ }^{6}$ Achmad Djuainidi dan Thobieb Al Asyhar, 2008. Menuju Era Wakaf Produktif. Jakarta: Mumtaz Publishing.

7 Al-Jamal, Ahmad Muhammad Abd al-Azhīm. 2007. al-Waqf al-Islâmī fi at-Tanmiyah alIqtishâdiyyah alMu'ashirah, h.115.
} 
organisasi atau lembaga masyarakat, baik aktif maupun pasif untuk mengubah tata kelola serta pelembagaan Wakaf secara profesional dan memiliki kredibilitas. Tentu masuk di dalamnya adalah pemahaman Nazhir yang juga merupakan rukun Wakaf. Nazhir dapat dikatakan sebagai aparat penegak hukum dalam pelaksanaan Wakaf selain juga Wakif dan PPAIW (Pejabat Pembuat Akta Ikrar Wakaf). Sedangkan menurut UU No. 41/ 2004 institusi yang memiliki wewenang sebagai penegak adalah Badan Wakaf Indonesia (BWI). Oleh sebabnya BWI memiliki peran yang sangat penting dalam pengelolaan Wakaf di Indonesia. ${ }^{8}$

Indikator keberhasilan pengelolaan Wakaf sendiri dapat dilihat dari eksistensi lembaga yang berperan untuk memajukan dan mengembangkan Wakaf secara nasional berikut payung hukumnya. Kedua hal tersebut secara langsung akan memberikan kesempatan yang seluas-luasnya kepada masyarakat dan umat Islam untuk melaksanakan Wakaf terhadap sebagian harta benda maupun kekayaan yang dimilikinya dalam memajukan kesejahteraan umum secara tenang dan ihlas. Kemudian daripada hal tersebut juga pengelolaan harta Wakaf baik itu benda tidak bergerak, benda bergerak juga masuk di dalamnya adalah pengelolaan Wakaf uang, yang kesemuanya dimaksudkan untuk pengembangan dan pemanfaatan potensi kekuatan ekonomi umat Islam dalam rangka untuk memajukan kesejahteraan umum, juga menyediakan sarana ibadah keagamaan dan sosial dapat dilaksanakan secara

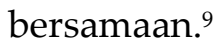

Seiring perkembangan zaman pelaksanaan Wakaf tidak lagi dikelola dengan cara tradisional dan apa adanya, bahkan pemerintah mendirikan lembaga resmi khusus menangani perwakafan. Pelaksanaannya meliputi aset benda tidak bergerak mencakup Wakaf masjid, Wakaf surau, dan Wakaf tanah pemakaman bahkan lebih modern dengan bentuk kontemporer yakni Wakaf tunai dan Wakaf produktif yang instrumen pelaksanaanya menjadi jembatan bagi siapa saja umat muslim yang ingin melaksanakan Wakaf dengan keterbatasan kemampuan. Hasil daripada Wakaf tersebut kemudian dikelola dan diproduktifkan untuk hasil sepanjang masa, sehingga Wakaf tidak terbatas pada masa dan lingkup tertentu saja. Kedua bentuk Wakaf kontemporer tersebut di atas dipandang sebagai solusi pendorong kesejahteraan umat yang menghasilkan sesuatu yang bermanfaat dalam jangka panjang kemaslahatan umat.

Selanjutnya dengan adanya perkembangan hukum guna melindungi harta benda Wakaf, pemerintah dengan persetujuan Dewan Perwakilan Rakyat pada tanggal 27 Oktober 2004 telah mengesahkan dan memberlakukan Undang-Undang Republik Indonesia Nomor 41 Tahun 2004 tentang Wakaf. Rumusan dalam undang-undang ini memasukkan nilai konsepsi fikih Wakaf baru di Indonesia yang antara lain meliputi benda yang diWakafkan (mauqūf bih); peruntukan Wakaf (mauqūf 'alayh); sighat Wakaf baik untuk benda tidak bergerak maupun benda bergerak seperti uang dan saham; kewajiban dan hak Nadhir Wakaf; dan lain-lain yang menunjang pengelolaan Wakaf produktif. Sebagai tindak lanjut dari lahirnya Undang-undang Wakaf, banyak lembaga

\footnotetext{
${ }^{8}$ Masykuri Abdillah, www.bw-Indonesia.net.

${ }^{9}$ Rachmadi Usman. 2009. Hukum Perwakafan di Indonesia. Jakarta: Sinar Grafika, h.26.
} 
pengelola Wakaf dan bank syariah meluncurkan produk dan fasilitas yang menghimpun dana Wakaf dari masyarakat. ${ }^{10}$ Baitul Mal Muamalat, meluncurkan Wakaf Tunai Muamalat (Waqtumu), Dompet Dhuafa Republika meluncurkan Tabung Wakaf Indonesia (TWI), dan Pos Keadilan Peduli Umat (PKPU) juga meluncurkan Wakaf uang. Lembaga-lembaga ini, sejatinya secara hukum masih terdaftar sebagai lembaga amil zakat yang melakukan pengelolaan Wakaf tunai. Semua lembaga ini banyak berperan agar pemanfaatan Wakaf untuk kepentingan luas maksimal.11

Pengelolaan Wakaf harus dilakukan secara profesional, transparan dan dapat dipertanggungjawabkan. Dalam Undang-Undang Republik Indonesia Nomor 41 Tahun 2004 Tentang Wakaf sudah mulai dijelaskan berbagai macam persoalan mengenai Wakaf, sebagai salah satu realisasi untuk melaksanakan amanat undangundang tersebut telah dibentuk juga Badan Wakaf Indonesia yakni terdapat pada Bab VI berdasarkan pada Pasal 47 Ayat 1 Undang-Undang Nomor 41 Tahun 2004 Tentang Wakaf yang menyebutkan bahwa dalam rangka memajukan dan mengembangkan perwakafan nasional, dibentuk Badan Wakaf Indonesia.

Dinamika perkembangan Wakaf di Indonesia mencapai puncaknya dengan lahirnya Undang-undang Nomor 41 Tahun 2004 Tentang Wakaf. Jika tidak adanya Badan Wakaf Indonesia, para nazhir dalam mengembangkan pengelolaan aset Wakaf akan banyak mengalami hambatan-hambatan terutama masalah sosialisasi terhadap masyarakat yang belum paham mengenai definisi maupun tata cara meWakafkan hartanya sehingga kadang para Wakif yang ingin berWakaf menjadi enggan berWakaf karena tidak tahu tata cara berWakaf. Persoalan yang dihadapi nazhir di Indonesia sebenarnya bukan hanya mengenai cara pengelolaan, akan tetapi juga menyangkut masalah pendanaaan yang diperlukan untuk mengembangkan benda Wakaf, sengketa tanah Wakaf dan lain-lain. Paradigma ini terus berlanjut karena tidak adanya pengawasan dan pembinaan dari pemerintah terhadap penyelesaian sengketa perwakafan dan berujung ke pengadilan. Dalam masalah pendanaan, Badan Wakaf Indonesia ikut andil mengarahkan nazhir untuk mendapatkan dana pemeliharaan harta Wakaf, sedangkan terhadap tanah Wakaf yang bermasalah, Badan Wakaf Indonesia juga berperan serta membantu menyelesaikannya.

Lembaga Wakaf merupakan salah satu pilar ekonomi Islam dan sangat erat kaitannya dengan masalah sosial ekonomi masyarakat. Adanya lembaga yang berperan menjadi peluang perwakafan bisa maju dan berkembang, dengan terobosan baru mengembangkan aset-aset Wakaf melalui manajemen bisnis yang profesional, sehingga meningkatkan hasil pengelolaan Wakaf. Dengan dibentuknya badan khusus yang bertugas dan berwenang untuk melakukan pembinaan terhadap para pengelola Wakaf (nazhir) dengan melakukan berbagai upaya seperti pelatihan, kerjasama dengan lembaga lain, advokasi, membuat percontohan dan lain-lain yang dapat menggairahkan nazhir dalam mengelola Wakaf. Hasil tersebut dapat menunjang pembangunan, baik dibidang ekonomi, agama, sosial, budaya, politik, pertahanan,

\footnotetext{
10 Sukanto, 1981, Meninjau Hukum Adat Indonesia Suatu Pengantar untuk mempelajari Hukum Adat, Jakarta: Rajawali Press

${ }^{11}$ Muhammad Syafi'i Antonio. 2007. Waqaf dan Anggaran Pendidikan Umat. Jakarta: Gema Insani.
} 
keamanan, yang pada akhirnya semua ditujukan untuk kesejahteraan masyarakat dimana merupakan tujuan utama dan esensi dari Wakaf itu sendiri.

Lembaga pengelolaan Wakaf seperti ini jauh telah dilakukan di negara tetangga kita yaitu Bangladesh, pemberdayaan potensi Wakaf secara produktif, keprofesionalan yang dilakukan meliputi, aspek manajemen, SDM nazhir, pola kemitraan usaha, bentuk Wakaf benda bergerak, seperti uang, saham, surat berharga lainnya, dan dukungan political will pemerintah secara penuh. Sejak tahun 1995 di negara itu didirikan Social Investment Bank Ltd. (SIBL) yang mengembangkan pasar modal sosial (The Voluntary Capital Market). Instrumen-instrumen keuangan Islam pun dikembangkan seperti Obligasi Pembangunan Wakaf Properti (Waqf Properties Development Bond), Sertifikat Wakaf Tunai (Cash Waqf Certificate). Wakaf uang di negara tersebut dapat menggantikan sebagian pajak penghasilan untuk pembangunan infrastruktur, sosial, dan kemanusiaan. ${ }^{12}$

Dengan adanya Badan Wakaf Indonesia diharapkan wajah perwakafan di Indonesia mengalami kemajuan juga berbagai persoalan Wakaf dapat teratasi. Di samping itu, sebagai lembaga independen juga diharapkan dapat menggali manfaat dan penghimpunan Wakaf selain juga pengelolaannya yang lebih profesional, transparan dan dapat dipertanggungjawabkan. Dalam hal mengurusi benda Wakaf yang telantar harus lebih optimal dan membantu pemerintah dalam bidang kebijakan regulasi Wakaf. Dilihat dari tugas dan fungsinya, mengingat Badan Wakaf Indonesia mempunyai tanggung jawab yang cukup berat untuk memberdayakan Wakaf di Indonesia.

Berdasarkan dari latar belakang diatas, maka Penulis merumuskan untuk mengangkat judul "Peran Badan Wakaf Indonesia Pasca Terbitnya Undang-Undang Nomor 41 Tahun 2004 Tentang Wakaf." Hal ini diyakini Penulis bahwa akan ada nilai histori yang mengantarkan pada setiap lahirnya undang-undang.

Adapun dalam penelitian ini peneliti akan fokus pada: Bagaimana peranan Badan Wakaf Indonesia terhadap pelaksanaan Wakaf di Indonesia? Bagaimana sistem pengelolaan Wakaf sebelum dan sesudah Undang-Undang Nomor 41 Tahun 2004 tentang Wakaf?

\section{B. METODE PENELITIAN}

Di dalam penelitian hukum terdapat beberapa pendekatan, dengan pendekatan tersebut, peneliti akan mendapatkan informasi dari berbagai aspek mengenai isu dan masalah yang sedang dicari jawabannya. Macam-macam pendekatan yang digunakan didalam penelitian hukum adalah: a. Pendekatan undang-undang (statutue approach); b. Pendekatan kasus (case approach); c. Pendekatan historis (historical approach); d. Pendekatan komparatif (comparative approach); e. Pendekatan konseptual (conceptual approach).

${ }^{12}$ Rachmadi Usman. 2009. Hukum Perwakafan di Indonesia. Jakarta: Sinar Grafika, h. 106. 
Pendekatan yang dilakukan oleh Penulis lebih ditujukan kepada pendekatan peraturan perundang-undangan (statue aproach) dan pendekatan historis. Suatu penelitian normatif tentu harus menggunakan pendekatan perundang-undangan, karena yang akan diteliti adalah berbagai aturan hukum yang menjadi fokus sekaligus tema sentral suatu penelitian. Pendekatan undang-undang dilakukan dengan menelaah semua undang-undang dan regulasi yang berkaitan dengan permasalahan hukum yang sedang ditangani. Pendekatan historis dilakukan dengan cara menelaah studi arsip-arsip yang mempunyai nilai-nilai historis. ${ }^{13}$

\section{HASIL TEMUAN DAN PEMBAHASAN}

\section{Landasan Teoritik tentang Wakaf}

Wakaf berasal dari bahasa Arab yang al Waqf yang merupakan bentuk masdar dari waqafa yang berarti menghentikan, berdiam di tempat atau menahan sesuatu. Makna menahan di sini bukan makna sesungguhnya sebagaimana seseorang yang duduk atau berdiam, namun secara interprestasi jika dikaitkan dengan harta adalah pembekuan hak milik untuk kegunaan tertentu, sehingga dapat diartikan menahan suatu harta untuk menggunakannya. ${ }^{14}$

Secara istilah wakaf bermakna sejenis pemberian yang pelaksanaannya dilakukan dengan jalan menahan (pemilikan) kemudian menjadikan manfaatnya untuk dapat berlaku secara umum. Sedangkan dalam Undang-undang Nomor 41 Tahun 2004 tentang Wakaf mendefinisikan yaitu, perbuatan hukum wakif untuk memisahkan dan atau menyerahkan sebagian harta benda miliknya untuk dimanfaatkan selamanya atau untuk jangka waktu tertentu sesuai dengan kepentingannya guna keperluan ibadah dan atau kesejahteraan umum menurut syariah.

Baik secara bahasa atau terminologis juga definisi menurut undang-undang, wakaf dapat didefinisikan bahwa Wakaf adalah suatu akad tabarru yaitu menahan pokok harta dan memberikan manfaat dari harta tersebut untuk kepentingan umat Islam. Wakaf memiliki tujuan untuk memeberikan manfaat atau faidah terhadap harta yang diwakafkan kepada orang yang berhak menerima akad tersebut dan dipergunakan sesuai dengan ajaran Islam.

Wakaf sendiri memiliki dua macam pelaksanaan, misalnya saja adalah wakaf keluarga (waqaf ahl) atau biasa disebut dengan wakaf khusus, adalah wakaf yang dikhususkan ata diperuntukkan bagi orang-orang tertentu, perorangan atau lebih baik yang memiliki hubungan keluarga maupun orang lain. Yang kedua disebut dengan Wakaf Umum (Waqf Khair), adalah wakaf yan diperuntukkan bagi kepentingan atau kemaslahatan umum, dalam wakaf khair ini sering dilaksanakan di Indonesia melalui

13 Johni Ibrahim. 2007. Teori dan Metodologi Penelitian Hukum Normatif. Malang: Bayumedia Publishng, h.300.

${ }^{14}$ Muhamad Ali Daud. 1998. Sistem Ekonomi Islam Zakat dan Wakaf. Jakarta: UI Press, h.80. 
lembaga-lembaga keagamaan, lembaga sosial, Masjid, Madrasah, Pesantren, Rumah sakit, rumah yatim piatu, pemakaman umum atau sebagainya. ${ }^{15}$

Memperhatikan dari kedua macam bentuk wakaf tersebut Wakaf umum (Waqf Khair), adalah wakaf yang benar-benar dapat dinikmati manfaatnya oleh masyarakat dan merupakan salah satu sarana penyelenggaraan kesejahteraan masyarakat baik dalam bidang keagamaan maupun bidang ekonomi serta pendidikan. Terlebih saat ini pelaksanaan wakaf dikembangakan dalam persfektif kontemporer dalam bentuk wakaf produktif, sehingga explorasi manfaat wakaf jauh dapat dihasilkan dengan cara maksimal dengan ijtihad yang para ulama. ${ }^{16}$

Hal lain yang juga menjadi baik untuk didalami terkait dua jenis wakaf di atas adalah dalam segi faidahnya misalnya saja satu segi, wakaf ahli ini mempunyai dua aspek kebaikan, yaitu (1) kebaikan sebagai amal ibadah wakaf, (2) kebaikan silaturrahmi terhadap keluarga yang diberikan harta wakaf. Namun, pada sisi lain wakaf ahli sering menimbulkan masalah, mengingat perkembangan hubungan kekeluargaan juga berkembangnya ahli waris. Berbeda dengan waqf khair Dari tinjauan penggunaannya, dalam wakaf khair ini lebih banyak manfaatnya ketimbang wakaf ahli, karena tidak terbatasnya pihak-pihak yang mengambil manfaat. Sesungguhnya jenis wakaf ini yang sesuai dengan hakikat wakaf dan secara substansial, wakaf ini juga merupakan salah satu cara membelanjakan (memanfaatkan) harta di jalan Allah yang urgensinya untuk memperoleh ridha Allah semata.

Dalam kajian histori wakaf telah dikenal sejak awal Islam, bahkan sebelum Islam masyarakat telah mempraktekkan sejenis perbuatan wakaf namun diidentifikasi bukanlah wakaf, mengingat syarat serta rukunnya tidak dipenuhi dalam praktek tersebut. Wakaf sendiri secara explisit tidak ditemukan dalam al-Quran maupun hadist. Namun demikian dalam beberapa kajian fikih Hadis Nabi menyebutnya dengan istilah lain yaitu abs (menahan) sebagai kata yang semakna dengan wakaf. Dalam menentukan dasar hukum para ulama cenderung mengqiyaskan wakaf dengan infaq demikian juga terkait dengan pelaksanaannya. Hal lain yan dijadikan rujukan oleh para ulama adalah pedoman pada hadis terkait istilah yang digunakan oleh Nabi. ${ }^{17}$

Praktek sejenis wakaf sebelum Islam dibuktikan dengan adanya tempat-tempat ibadah yang dibangun di atas tanah pekarangan seseorang yang dikelola dan hasilnya untuk membiayai perawatan dan memberikan upah pengelola tempat ibadah tersebut. Bahkan di wilayah lain praktek serupa juga telah dilaksanakan, misalnya saja di Roma, Mesir, Jerman dan beberapa tempat lainnya. Selanjutnya mengingat praktek sejenis wakaf terjadi pada msyarakat sebelum Islam yang juga memiliki tujuan yang seiring dengan Islam yaitu terdistribusinya kekayaan secara adil dan kemudian berujung pada

\footnotetext{
${ }^{15}$ Muhamad Ali Daud. 1998. Sistem Ekonomi Islam Zakat dan Wakaf. Jakarta: UI Press, h.84.

${ }^{16}$ Naziroeddin Rachmat. 1994. Harta Wakaf, Pengertian dan Perkembangan dan Sejarahnya di dalam Masyarakat Islam Dulu dan Sekarang. Jakarta: Bulan Bintang, h.60.

17 Havis Aravik, Nur Rohim Yunus, Dwi Sulastyawati. 2019. Legal Politics of Waqf-Regulation In Indonesia. Nur El-Islam; Jurnal Pendidikan dan Sosial Keagamaan. Volume 6, No. 1 (2019).
} 
kesejahteraan bersama maka kemudian Islam mengakomodir nilai-nilai tersebut dengan sebutan wakaf. ${ }^{18}$

Wakaf pada masa Islam dimulai pada tahun kedua hijriah setelah Nabi Muhammad SAW Hijrah dari Mekkah ke Madinah bersama dengan kenabian Muhammad di Madinah yang ditandai dengan pembangunan Masjid Quba', peristiwa ini terjadi setelah nabi hijrah ke Madinah yang kemudian dilanjutkan dengan pembangunan Masjid al Nabawi yang dibangun di atas tanah anak yatim dari Bani Al Najjar setelah tanah tersebut dibeli oleh Rasulullah dengan harga delapan ratus dirham.

Pelaksanaan wakaf juga dilakukan oleh para sahabat dalam banyak riwayat diceritakan bahwa Umar Ibn al Khattab, Abu Talhah atas perkebunannya. Riwayat lain juga menceritakan bahwa Abu Bakar Usman bin Affan, Ali Ibn Thalib Mu'az Ibn Jabal dan sahabat nabi yang lain yang juga mewakafkan hartanya untuk kemaslahatan umat. Wakaf kemudian mencapai perkembangannya di masa dinasti Umaiyyah dan dinasti Abbasiyyah, yang mana pada fase ini banyak masyarakat ingin mewakafkan hartanya bukan hanya sekedar membantu orang miskin namun juga menjadi modal untuk membangun lembaga pendidikan, fasilitas umum sebagaimana syariat juga untuk memberikan beasiswa. ${ }^{19}$

Maka dapat disimpulkan bahwa wakaf yang semula hanya sebuah niatan untuk melakukan perbuatan baik dengan kekayaan yang dimilikinya dan dikelola secara individu dan apa adanya namun setelah mengetahui manfaat dari wakaf maka timbullah keinginan untuk mengatur perwakafan secara profesional, terlembaga sehingga kemudian dibentuklah lembaga yang mengatur tentang wakaf berikut dengan pengelolaannya.

Wakaf dapat dikatakan ibadah yang memiliki instrumen ekonomi Islam yang memiliki peran multi dimensi, berdasarkan fungsinya dimensi kebajikan (bir) dilaksanakan melalui wakaf, juga dimensi kebaikan (ihsan) dan persaudaraan (ukhuwah) yang saat bersamaan juga dilaksanakan ketika seseorang sedang melaksanakan wakaf. Hal utama yang sangat khas dari wakaf daripada ibadah yang lain adalah ketika wakaf ditunaikan terjadi pergeseran kepemilikan pribadi menuju kepemilikan Allah SWT, yang memiliki sifat abadi, memberikan manfaat secara berkelanjutan. Melalui wakaf upaya distribusi manfaat bagi masyarakat secara luas dari hanya sekedar manfaat pribadi (Private benefit) menuju manfaat masyarakat umum (social benefit). Kekekalan objek wakaf menjadi salah satu doktrin utama untuk melestarikan keberadaan wakaf, sedangkan modifikasi serta inovasi yang digali melalui ijtihad merupakan pemberdayaan harta wakaf agar tidak stagnan dan statis di tempat, misalnya saja dari salah satu rukun wakaf yang mengharskan adanya wakif yang dulu direpresentasikan sebagai bentuk perseorangan namun dengan inovasi

\footnotetext{
${ }^{18}$ Havis Aravik, Nur Rohim Yunus, Dwi Sulastyawati. 2019. Legal Politics of Waqf-Regulation In Indonesia. Nur El-Islam; Jurnal Pendidikan dan Sosial Keagamaan. Volume 6, No. 1 (2019)

${ }^{19}$ Havis Aravik, Nur Rohim Yunus, Dwi Sulastyawati. 2019. Legal Politics of Waqf-Regulation In Indonesia. Nur El-Islam; Jurnal Pendidikan dan Sosial Keagamaan. Volume 6, No. 1 (2019)
} 
wakif saat ini juga dalam bentuk lembaga sebagaimana tuntutan masyarakat atas kredibilitas, transparasi juga hasil daya yang maksimal.

Pelaksanaan wakaf dinyatakan sah bila memenuhi rukun dan syaratnya yang telah ditentukan. Adapun rukun wakaf menurut fiqh terdiri dari empat macam, yaitu (1) waqif (orang yang mewakafkan), (2) Mauquf'alaih (pihak yang diserahi wakaf), (3) Mauquf (harta yang diwakafkan), juga (4) Shighat atau iqrar (pernyataan atau ikrar wakif sebagai suatukehendak untuk mewakaf kan). Adpaun hal tersebut di atas dirinci sebagai berikut:

a. Waqif (orang yang mewakafkan). Wakif harus mempunyai kecakapan hukum atau kamalul ahliyah (legal competent) dalam membelanjakan hartanya (tasharruf al-mal). Kecakapan tersebut meliputi 4 kriteria yaitu: (1) Merdeka; (2) Berakal sehat, (3) Dewasa atau baligh, (4) tidak dibawah pengampuan;

b. Mauquf 'alaih (orang yang diberi amanat wakaf). Mauquf 'alaih dalam literatur fiqh kadang diartikan orang yang diserahi mengelola harta wakaf, yang sering disebut nadzir, kadang juga diartikan peruntukan harta wakaf. Berkenaan dengan keyakinan nadzir, Imam Nawawi mengatakan sah hukumnya wakaf kepada kafir dzimmi dengan 2 syarat, (1) peruntukan objek wakaf yang diamanatkan kepada nadzir tidak berupa ibadah bagi muslim, seperti wakaf Qur'an kepada nadzir kafir dzimmi, dan (2) manfaat benda wakaf oleh nadzir tidak untuk kepentingan keyakinan si kafir dzimmi seperti wakaf untuk pembangunan gereja yang difasilitasi oleh nadzir kafir dzimmi. ${ }^{20}$

c. Mauquf (Harta Benda Wakaf). Perbincangan fiqh mengenai benda wakaf, bertolak pada, pertama, jenis harta, apakah benda bergerak atau tidak bergerak, atau bisa keduanya. Madzhab Syafi'iyah dan Hanbaliyah tergolong konservatif dengan hanya membolehkan harta tak bergerak sebagai objek wakaf. Sementara Hanafiyah dan Malikiyah cenderung membolehkan wakaf harta bergerak. Perbedaan ini muncul dari perbedaan menafsirkan apakah yang diwakafkan adalah dzat benda atau manfaat benda. Bila dzat benda maka cenderung benda tidak bergerak yang ternyata jumlah jenisnya sedikit, sedangkan bila manfaat benda cenderung benda bergerak yang jumlah jenisnya sangat banyak.

d. Shighat (pernyataan atau ikrar wakif). Shighat atau ikrar adalah pernyataan penyerahan harta benda wakaf oleh wakif. Dalam hal ini perbedaan yang muncul adalah bentuk pernyataan apakah lisan, kinayah atau tindakan. Sementara dalam hal akad wakaf, semua madzhab menyatakan bahwa wakaf adalah akad tabarru' yaitu transaksi sepihak yang sah sebagai suatu akad yang tidak memerlukan kabul dari pihak penerima dan dicukupkan dengan ijab si wakif Akad tidaklah menjadi syarat dalam akad wakaf. Definisi akad disini adalah suatu bentuk perbuatan hukum (tasharruf) yang mengakibatkan adanya

\footnotetext{
${ }^{20}$ Muhammad Sesse Sudirman. 2010 "Wakaf dalam Persfektif Fikih Dan Hukum Nasional", dalam Jurnal Hukum Diktum, Vol 8/ Nomor 2, Juli 2010 STAIN (Sekolah Tinggi Agama Islam Negeri) Parepare, h.147.
} 
kemestian penataan kepada apa yang dinyatakan dari kehendak perbuatan hukum itu oleh pihak yang berkepentingan, kendatipun pernyataan itu dari sepihak saja. Akad dalam pengertian kesepakatan dari dua belah pihak yang berkehendak melakukan suatu perikatan digambarkan dengan ijab dan qabul seperti yang terjadi dalam jual beli, sewa menyewa, dan sebagainya, sehingga tidaklah berlaku dalam pengertian akad wakaf.

\section{Pelaksanaan Wakaf Sebelum Undang-undang Nomor 41 Tahun 2004}

Krisis ekonomi yang dialami bangsa Indonesia, sejak Juli 1997, merambat ke berbagai aspek kehidupan berbangsa dan bernegara. Melemahnya kegiatan perekonomian, sebagai akibat depresiasi nilai tukar yang sangat tajam dan inflasi yang tinggi, tidak hanya menyebabkan merosotnya tingkat pertumbuhan ekonomi, tetapi juga memaksa sektor ekonomi lainnya menurunkan atau bahkan menghentikan usahanya. Keadaan ini, mengakibatkan bertambahnya pengangguran yang pada gilirannya memicu berbagai masalah sosial seperti meningkatnya angka kemiskinan dan kriminalitas yang mengancam stabilitas politik. ${ }^{21}$

Krisis yang berkepanjangan sampai akhir tahun 2007 semakin memperparah keadaan. Tingkat kemiskinan di Indonesia, berdasarkan data BPS tahun 2007 telah berkurang menjadi 16,5\%, turun drastis dibandingkan dengan awal tahun 1998 yang mencapai $24,2 \%$. Data yang dibuat oleh BPS, ternyata tak lebih hanya dalam angka semata, tidak sesuai dengan fakta karena kenyataannya tingkat kemiskinan di Indonesia masih tinggi yakni 49,5\% dengan merujuk pada standar Bank Dunia. Keadaan ini disebabkan karena sektor rill tidak bergerak, yang berakibat PHK terus terjadi karena alasan keterpurukan ekonomi; antara lapangan kerja yang tersedia dengan jumlah tenaga kerja tidak seimbang. Sejumlah persoalan-persoalan sosial timbul terutama pengangguran dan kemiskinan masih menjadi pekerjaan rumah bagi pemerintah.

Penyakit kronis ini sebetulnya ada solusinya karena Islam memiliki konsep yang solutif di antaranya dengan menjadikan zakat dan Wakaf sebagai bagian dari sumber pendapatan negara. Islam memiliki konsep pemberdayaaan ekonomi umat, yaitu dengan memaksimalkan peran lembaga pemberdayaan ekonomi umat seperti Wakaf dan zakat. Sebetulnya kalau Wakaf dikelola secara baik dapat meningkatkan taraf hidup masyarakat.

Dalam konteks negara Imdonesia pelaksanaan wakaf sudah dilaksanakan oleh masyarakat Islam sejak sebelum kemerdekaan, namun mengingat pelaksanaan wakaf dilaksanakan secara tradisional dan apa adanya maka kemudian hasil daya dari pelaksanaan dan pengelolaan wakaf juga kurang maksimal. Selama ini, peruntukan Wakaf di Indonesia kurang mengarah pada pemberdayaan ekonomi umat, cenderung terbatas hanya untuk kepentingan kegiatan ibadah, pendidikan, dan pemakaman

${ }^{21}$ Muhammad Abdul Mannan, 1987. The Institution of Waqf: Its Religius and Socio-Economic Roles and Implications dalam Management and Developmen of Awqaf Properties, Proceeding of the Seminar, Jeddah: Islamic Research and Training Institute, Islamic Developmen Bank. 
semata, kurang mengarah pada pengelolaan Wakaf produktif. Beban sosial ekonomi yang dihadapi bangsa saat ini, seperti tingginya tingkat kemiskinan dapat dipecahkan secara mendasar dan menyeluruh melalui pengelolaan Wakaf dalam ruang lingkup yang lebih luas yakni pengelolaan Wakaf produktif. Untuk melihat potret perkembangan Wakaf di Indonesia, akan diawali dengan menguraikan sekilas sejarah perkembangan Wakaf dan regulasi yang dilakukan terhadap perwakafan di Indonesia.

Sejarah perkembangan Wakaf di Indonesia sejalan dengan penyebaran Islam di seluruh wilayah nusantara. Di samping melakukan dakwah Islam, para ulama juga mengajarkan Wakaf pada umat Islam untuk menyerahkan tanahnya sebagai Wakaf. Ajaran Wakaf di bumi Nusantara terus berkembang terbukti dengan banyaknya masjid-masjid bersejarah yang dibangun di atas tanah Wakaf. Bahkan dapat dikatakan bahwa wakaf di Indonesia lebih cenderung dilaksanakan sebagai sebuah hukum adat di Indonesia meskipun wakaf adalah salah satu pranata hukum Islam namun penerimaan lembaga wakaf berasal dari suatu kebiasaan, oleh sebabnya pada masa penjajahan wakaf hanya diatur dalam hukum adat yang sifatnya tidak tertulis dengan mengambil rujukan dari hukum Islam.

Selanjutnya dalam sejarah juga didapati bahwa pada masa kolonialisme didirikan suatu lembaga yang disebut priesterrad (Peradilan Agama) berdasarkan staatsbald Nomor 152 pada tahun 1882 yang menangani khusus sengketa agama yang wewenangnya meliputi perkawinan, waris, hibah, sedekah dan hal-hal lain yang dianggap berhubungan erat dengan hukum Islam, termasuk di dalamnya adalah masalah wakaf. Legitimasi dari Kolonialis ini didasarkan pada pada kenyataan bahwa penyelesaian sengketa mengenai masalah wakaf dan lain-lainnya yang berhubungan dengan hukum Islam diajukan oleh masyarakat ke Mahkamah Syariah atau peradilan Agama lokal. ${ }^{22}$

Seiring dengan perkembangan sosial masyarakat Islam, praktek perwakafan mengalami kemajuan dari waktu ke waktu. Sejarah pengelolaan Wakaf di Indonesia mengalami beberapa fase. Paling tidak ada tiga fase besar pengelolaan Wakaf di Indonesia yakni,

\section{1) Periode Tradisional}

Pada fase ini Wakaf masih ditempatkan sebagai ajaran yang murni. Ajaran Wakaf dimasukkan dalam kategori ibadah mahdhah, yaitu benda-benda Wakaf diperuntukan kebanyakan untuk pembangunan fisik, seperti untuk masjid, mushalla, pesantren, tanah pekuburan, dan sebagainya. Pada periode ini keberadaan Wakaf belum memberikan kontribusi sosial yang lebih luas karena untuk kepentingan yang bersifat konsumtif. Di Indonesia, dari data yang dimiliki Departemen Agama RI tentang tanah Wakaf di seluruh Indonesia menunjukkan bahwa luas tanah Wakaf adalah 1.566.672.406 M2 dan terletak pada 403.845 lokasi. Namun demikian, fungsi Wakaf secara khusus sebagai pemberdaya ekonomi masyarakat tidak dapat dipungkiri, masih kurang dirasakan atau bahkan tidak sama sekali. Selama ini, distribusi aset Wakaf di Indonesia cenderung kurang mengarah pada pemberdayaan

${ }^{22}$ Notosusanto, Peradilan Agama Islam di Djawa dan Madura, (Yogyakarta: Tnp., 1953), h. 77 
ekonomi umat dan hanya berpretensi untuk kepentingan kegiatan-kegiatan ibadah mahdah. Pada fase ini, pada umumnnya umat Islam di Indonesia memahami bahwa peruntukan Wakaf hanya terbatas untuk kepentingan peribadatan, seperti masjid, mushalla, sekolah, makam, dan lain-lain. Peruntukan yang lebih menjamin produktivitas dan kesejahteraan umat nampaknya masih belum diterima sebagai yang inheren dalam Wakaf.

\section{2) Periode Semi Profesional}

Periode ini merupakan masa pengelolaan Wakaf secara umum masih sama dengan fase tradisional. Namun, pada masa ini sudah mulai dikembangkan pola pemberdayaan Wakaf produktif, meskipun belum maksimal. Misalnya, penambahan fasilitas gedung pertemuan, pernikahan, toko atau mini market, dan fasilitas lainnya yang berada dalam pekarangan masjid yang dibangun di tanah Wakaf. Seperti yang telah dilakukan di Masjid Pondok Indah Jakarta, Masjid Taqwa Kota Padang, dan beberapa masjid lainnya di Indonesia. Hasilnya digunakan untuk biaya operasional masjid atau untuk anak yatim piatu. Gedung atau ruangan tersebut disewakan. Selain itu, juga mulai dikembangkan pemberdayaan tanah Wakaf untuk pertanian, Pendirian tempat usaha seperti toko, koperasi, perbengkelan, penggilingan padi. Hasil usaha digunakan untuk kepentingan pengembangan di bidang pendidikan. Seperti yang dilakukan Pondok Pesantren Modern As-Salam Gontor, Badan Wakaf Universitas Indonesia, dan yayasan pendidikan lainnya. Kemajuan pengelolaan Wakaf yang dilakukan di Indonesia tersebut setidaknya sudah hampir mendekati kemajuan pengelolaan Wakaf yang telah dilakukan Mesir. Seperti Universitas Al-Azhar di Kairo dengan Wakaf yang amat besar, Universitas mampu membiayai operasional pendidikannya selama berabad-abad tanpa bergantung pada pemerintah. Bahkan Universitas tersebut mampu memberikan beasiswa kepada ribuan mahasiswa dari seluruh penjuru dunia selama berabad-abad.

\section{3) Periode Profesional.}

Periode ini ditandai dengan pemberdayaan potensi Wakaf secara produktif. Keprofesionalan yang dilakukan meliputi, aspek manajemen, SDM nazhir, pola kemitraan usaha, bentuk Wakaf benda bergerak, seperti uang, saham, surat berharga lainnya, dukungan political will pemerintah secara penuh dengan lahirnya Undangundang Nomor 41 Tahun 2004 Tentang Wakaf. Semangat pemberdayaan potensi Wakaf secara produktif dan profesional adalah untuk kepentingan kesejahteraan umat manusia di bidang ekonomi, pendidikan, kesehatan, maupun bidang sosial lainnya. Lembaga pengelola dana Wakaf menyalurkan kepada sektor riil secara mudhârabah, atau menginvestasikannya di sektor keuangan syari'ah. Kemudian hasilnya diberikan kepada mauquf 'alaih sesuai dengan tujuan Wakaf, seperti yang dilakukan oleh Tabung Wakaf Indonesia Dompet Dhuafa Republika, Wakaf uang Muamalat Baitul Mal Muamalat. Hasil dari pengembangan itu dipergunakan untuk keperluan sosial, seperti untuk meningkatkan pendidikan Islam, pengembangan rumah sakit Islam, 
bantuan pemberdayaan ekonomi umat, dan bantuan untuk pengembangan sarana dan prasarana ibadah.

Pengelolaan Wakaf seperti ini jauh sebelumnya telah dilakukan di Bangladesh. Sejak tahun 1995 di negara itu didirikan Social Investment Bank Ltd. (SIBL) yang mengembangkan pasar modal sosial (The Voluntary Capital Market). Instrumeninstrumen keuangan Islam pun dikembangkan seperti obligasi pembangunan Wakaf properti (Waqf Properties Development Bond), Sertifikat Wakaf Tunai (Cash Waqf Certificate). Wakaf uang di negara tersebut dapat menggantikan sebagian pajak penghasilan untuk pembangunan infrastruktur, sosial, dan kemanusiaan. Hasil dari pengembangan itu dipergunakan untuk keperluan sosial pembangunan negara. ${ }^{23}$

Salah satu faktor penting yang ikut mewarnai corak dan perkembangan Wakaf di era modern adalah ketika negara ikut mengatur kebijakan Wakaf melalui seperangkat hukum positif. Dalam proses perumusan kebijakan tersebut, ditentukan oleh bagaimana penguasa melihat potensi maupun organsiasi Wakaf, baik dalam kerangka kepentingannya, maupun kepentingan umat Islam pada umumnya. Secara umum dapat dikatakan bahwa kebijakan mengenai Wakaf atau filantropi Islam pada umumnya dibuat berdasarkan asumsi-asumsi ideologis menyangkut relasi antara Islam dan negara serta pertanyaan mengenai seberapa jauh Islam boleh berperan di ruang publik. Di masa penjajahan, kegiatan perwakafan mengalami perkembangan yang pesat. Hal itu ditandai dengan banyaknya muncul organisasi keagamaan, sekolah madrasah, pondok pesantren, masjid, yang semuanya dibangun dengan swadaya masyarakat di atas tanah Wakaf. Politik pemerintah pada masa ini mengenai filantropi Islam tunduk pada rasionalitas politik Islam Hindia Belanda. Di mana Islam sebagai sistem nilai dibatasi sedemikian rupa sehingga ia dipraktekkan dalam kerangka ritualpersonal semata. Rasionalitas semacam ini membuat tradisi Wakaf sebagai lembaga pelayanan sosial.

Faktanya, peraturan yang dibuat tidak sepenuhnya didasarkan pada keinginan politik (political will) yang jujur serta pemahaman yang benar tentang hakikat dan tujuan Wakaf. Akibatnya, peraturan-peraturan ini mendapat reaksi dari organisasiorganisasi Islam karena orang yang akan berWakaf harus mendapat izin pemerintah. Sementara itu umat Islam memandang perwakafan merupakan tindakan hukum privat sehingga tidak perlu ada izin dari pemerintah. Reaksi ini merupakan penolakan terhadap campur tangan pemerintah kolonial terhadap urusan-urusan yang berhubungan dengan agama Islam. Ini berarti peraturan yang dikeluarkan pemerintah kolonial tidak memiliki arti penting bagi pengembangan Wakaf, selain untuk memenuhi formalisme administratif semata. Formalisme ini terus berlangsung sampai masa kemerdekaan. Politik filantropi Islam pada masa Orde Lama tidak mengalami perubahan mendasar. Peraturan-peraturan yang mengatur perwakafan zaman kolonial, pada zaman kemerdekaan masih tetap diberlakukan, karena peraturan perwakafan yang baru belum ada. Adapun peraturan yang mengatur Wakaf pada masa orde lama adalah:

${ }^{23}$ Tim Depag, 2006. Pedoman Pengelolaan dan Pengembangan Wakaf. Jakarta: Bimas Islam, h.113. 
(1) Peraturan Pemerintah Nomor 33 Tahun 1949 yang memberikan kewenangan kepada Menteri Agama untuk mengurus Wakaf. Selanjutnya PP ini ditindaklanjuti oleh Peraturan Menteri Agama Nomor 9 Tahun 1952 yang memberikan kewenangan kepada Kepala Kantor Urusan Agama Kabupaten untuk menyelidiki, mendata, dan mengawasi penyelenggaraan perwakafan. Surat Keputusan Bersama Menteri Dalam Negeri dan Menteri Agraria Tanggal 5 Maret 1959 Nomor Pem.19/22/23/7: S.K./62/Ka/59P., mengalihkan kewenangan bupati sebagai pengawas harta Wakaf menjadi tugas Kepala Pengawasan Agraria. Secara hirarki peraturan hukum di Indonesia, jelas peraturan-peraturan ini masih lemah. Kemudian, aturan tentang Wakaf dimasukkan dalam undang-undang agraria. ${ }^{24}$

(2) Undang-undang Nomor 5 Tahun 1960 tentang Peraturan Dasar Pokok-pokok Agraria. Dalam Pasal 49 undang-undang ini menyatakan, negara melindungi keberlangsungan perwakafan di Indonesia dengan mengaturnya secara khusus dalam peraturan pemerintah. Namun, peraturan pemerintah itu baru lahir tahun 1977. Peraturan-peraturan yang dikeluarkan pemerintah Indonesia berkaitan dengan perwakafan seperti yang terjadi pada orde lama tidak memiliki arti penting bagi pengembangan Wakaf selain hanya untuk memenuhi formalisme administratif semata. Hal ini dikarenakan pemerintah pada masa orde baru ini lebih berkonsentrasi untuk memperkuat diri di atas kekuatan-kekuatan sipil terutama Islam, sembari menjalankan agenda sekularisasi politiknya secara konsisten, malah Islam hampir termarginalkan. Keadaan ini terus berlangsung sampai paroh kedua dasarwarsa 1980-an ketika secara mengejutkan Islam mulai diterima di ruang publik. Adapun peraturan perwakafan yang lahir pada masa orde baru adalah:

(a) Peraturan Pemerintah Nomor 28 tahun 1977 tentang Perwakafan Tanah Milik. Dengan adanya peraturan pemerintah ini, perwakafan tanah milik di Indonesia mulai memasuki babak baru. Perwakafan tanah milik di Indonesia mulai tertib dan terjaga. Ini merupakan peraturan pertama yang memuat substansi dan teknis perwakafan. Selama ini di Indonesia, peraturan yang mengatur perwakafan kurang memadai sehingga banyak muncul persoalan perwakafan di tengah masyarakat, seperti banyaknya sengketa tanah Wakaf. Tanah Wakaf yang statusnya tidak jelas, banyak benda Wakaf yang tidak diketahui keadaannya, penyalahgunaan harta Wakaf, dan sebagainya. Hal ini karena tidak adanya keharusan untuk mendaftarkan benda-benda Wakaf. Barulah dengan ditetapkannya peraturan pemerintah ini perwakafan mempunyai dasar hukum yang kuat. Dengan keluarnya peraturan pemerintah ini, seluruh peraturan yang mengatur perwakafan seperti yang tercantum dalam Tambahan Lembaran Negara Nomor 6196 tahun 1905, dan Tambahan Lembaran Negara Nomor tahun 1931 Nomor 12573, serta Tambahan Lembaran Negara Nomor tahun 1935 Nomor 13480 sepanjang bertentangan dengan Peraturan Pemerintah

${ }^{24}$ Rachmadi Usman, 2009. Hukum Perwakafan di Indonesia. Jakarta: Sinar Grafika, h.11-13. 
nomor 28 tahun 1977 ini dinyatakan tidak berlaku lagi. Selanjutnya, peraturan pemerintah ini ditindaklanjuti dengan keluarkannya Peraturan Menteri Dalam Negeri Nomor 6 Tahun 1977 Tentang Pendaftaran Perwakafan Tanah Milik, dan Peraturan Menteri Agama Nomor 1 Tahun 1978 Tentang Peraturan Pelaksana Peraturan Pemerintah Nomor 28 Tahun 1977 Tentang Perwakafan Tanah Milik dan peraturan pelaksana teknis lainnya. Walaupun peraturan pemerintah telah dikeluarkan, dalam perjalanannya ternyata perturan-peraturan perwakafan yang ada ini belum berjalan secara efektif dalam menertibkan perwakafan di Indonesia. Untuk itu tanggal 30 November 1990 dikeluarkan Instruksi Bersama Menteri Agama dan Kepala Badan Pertanahan Nasional Nomor. 4 Tahun 1990 dan Nomor 24 Tahun 1990 Tentang Sertifikat Tanah Wakaf.

(b) Instruksi Presiden Nomor 1 Tahun 1991 Tentang Kompilasi Hukum Islam. Instruksi yang dikeluarkan tangggal 5 Februari 1991 ini adalah pedoman bagi instansi pemerintah dan masyarakat yang memerlukannya dalam menyelesaikan masalah-masalah di bidang perwakafan khususnya yang termuat dalam buku III. Kemudian inpres ini ditindaklanjuti dengan Surat Keputusan Menteri Agama No 154 Tahun 1991 Tanggal 22 Juli 1991, meminta kepada seluruh instansi di lingkungan Departemen Agama termasuk Peradilan Agama untuk menyebarluaskan KHI. Aturan yang dimuat dalam buku III tentang perwakafan ini membawa pembaharuan dalam pengelolaan Wakaf walaupun secara substansi masih berbentuk elaborasi dari aturan yang termuat dalam Peraturan Pemerintah Nomor 28 Tahun 1977 Tentang Perwakafan Tanah Milik. Di sisi lain, instruksi presiden yang terdapat dalam buku III ini sebetulnya belum cukup merevitalisasi sektor Wakaf. KHI masih mengadopsi paradigma lama yang literal yang cenderung bersifat fiqh minded. Hal ini terlihat dari materi hukum yang dicakup merupakan bentuk unifikasi pendapat-pendapat mazhab dan Hukum Islam di Indonesia yang berkaitan dengan perwakafan.

\section{Pelaksanaan Wakaf Setelah Undang-undang Nomor 41 Tahun 2004}

Sejalan dengan bergulirnya gelombang reformasi dan demokratisasi di penghujung tahun 1990-an, membawa perubahan dan mengokohkan Islam sebagai salah satu kekuatan politik di panggung nasional, sampai munculnya undang-undang yang secara khusus mengatur Wakaf. Pemerintah RI mengakui aturan hukum perwakafan dalam bentuk undang-undang. Pada masa reformasi, peraturan perwakafan berhasil disahkan adalah Undang-undang Nomor 41 Tahun 2004 Tentang Wakaf dan Peraturan Pemerintah Nomor 42 Tahun 2006 Tentang Pelaksanaan Undang-undang Nomor 41 Tahun 2004 Tentang Wakaf.

Produk undang-undang ini telah memberikan pijakan hukum yang pasti, kepercayaan publik, serta perlindungan terhadap aset Wakaf. Pengesahan undangundang ini merupakan langkah strategis untuk meningkatkan kesejahteraan umum, 
meningkatkan peran Wakaf, tidak hanya sebagai pranata keagamaan saja, tetapi juga memiliki kekuatan ekonomi yang potensial untuk memajukan kesejahteraan umum. Di samping itu, dengan disahkannya undang-undang ini, objek Wakaf lebih luas cakupannya tidak hanya sebatas benda tidak bergerak saja, tapi juga meliputi benda yang bergerak seperti uang. Campur tangan pemerintah terhadap Wakaf hanya bersifat pencatatan dan mengawasi pemeliharaan benda-benda Wakaf agar sesuai dengan tujuan dan maksud Wakaf.

Pemerintah sama sekali tidak mencampuri, menguasai, atau menjadikan benda Wakaf menjadi milik negara. Kehadiran Undang-undang Nomor 41 Tahun 2004 Tentang Wakaf secara simbolik menandai kemauan politik negara untuk memperhatikan permasalahan sosial umat Islam. Namun demikian dalam Pasal 70 UU Nomor 41 tahun 2004 mengatakan: "Semua peraturan perundang-undangan yang mengatur mengenai perwakafan masih tetap berlaku sepanjang tidak bertentangan dan/ atau belum diganti dengan peraturan yang baru berdasarkan undang-undang ini"

Perkembangan peraturan perundang-undangan tentang Wakaf hari ini sangat ditentukan oleh dinamika internal umat Islam serta hubungan harmonis antara Islam dan negara. Iklim politik yang kondusif ini memungkinkan berkembangnya filantropi Islam seperti Wakaf. Selain itu, demokrasi menyediakan arena bagi artikulasi politik Islam secara konstitusional. Pada akhirnya, politik filantropi Islam ditentukan oleh proses integrasi/nasionalisasi gagasan sosial-politik Islam ke dalam sistem dan konfigurasi sosial maupun politik nasional yang memiliki Undang-undang Nomor 41 Tahun 2004 Tentang Wakaf ini menjadi momentum pemberdayaan Wakaf secara produktif sebab di dalamnya terkandung pemahaman yang komprehensif dan pola manajemen pemberdayaan potensi Wakaf secara modern. Jika dapat direalisasikan, akan memunculkan pengaruh yang berlipat ganda terutama dalam kaitannya dengan pemberdayaan ekonomi umat. ${ }^{25}$

Undang-Undang Nomor 41 tahun 2004 Tentang Wakaf diproyeksikan sebagai sarana rekayasa sosial (social engineering), melakukan perubahan-perubahan pemikiran, sikap dan perilaku umat Islam agar senafas dengan semangat undangundang tersebut. Dengan disahkannya undang-undang Wakaf, agenda politik umat bergeser dari orientasi ideologis menuju visi sosial ekonomi yang lebih pragmatis. Situasi ini membantu pembentukan proses integrasi gagasan sosial politik Islam ke dalam sistem dan konfigurasi sosial politik nasional. Umat mulai menyadari bahwa eksistensi mereka lebih bermakna. Apabila mereka kuat secara sosial dan ekonomi dan tidak hanya sekedar unggul dalam statistik. Dengan posisi sosial ekonomi yang kuat, negara akan lebih memperhitungkan berbagai aspirasi, negosiasi, dan gerakan umat Islam. ${ }^{26}$

Memperhatikan konteks dan latar belakang lahirnya undang-undang Wakaf, sangat terkait dengan motif politik, ekonomi, dan tertib hukum. Selain bermaksud mengakomodasi kepentingan sosial-religius umat Islam, pemerintah menyadari

\footnotetext{
25 Achmad Djunaidi; dan Thobieb Al-Asyhar. 2008. Menuju Era Wakaf Produktif. Jakarta: Mumtaz Publishing, h.90.

${ }^{26}$ Rahardjo, Satjipto. 1986. Hukum dan Masyarakat. Bandung: Angkasa, h.117.
} 
bahwa berkembanganya lembaga Wakaf dapat meningkatkan kesejahteraan sosial masyarakat. Karenanya tidak mengherankan, pemerintah diwakili Departemen Agama memainkan peranan yang signifikan dalam menginisiasi dan menfasilitiasi lahirnya seperangkat peraturan filantropi, khususnya Undang-undang Nomor 41 Tahun 2004 Tentang Wakaf. Sesuai dengan kehendak politik yang tertuang dalam undang-undang ini pemerintah bukanlah sebagai pelaksana operasional pengelola Wakaf tetapi pemerintah hanya berfungsi sebagai regulator, motivator, fasilitator, dan publik servis bagi pengelolaan Wakaf. Dalam menjalankan tugasnya, pemerintah dibantu oleh Badan Wakaf Indonesia (BWI).

Selain dari pada itu dinamika sosial, desakan publik dan perubahan paradigma berpikir yang semakin meluas memandang wakaf memaksa Undang-undang nomor 41 tahun 2004 lahir sebagai payung hukum yang lebih kuat berskala nasional dari yang tadinya dilaksanakan atas dasar hukum yang integral. Hal lain yang sangat menarik untuk dicermati dalam pelaksanaan wakaf menurut Undang-undang Nomor 41 Tahun 2004 adalah Undang-undang tersebut tidak menyebtkan kata muslim sebagai syarat wakif, bahkan pada tanggal 13 Septeber 2004, Panitia kerja pembahasan RUU wakaf yang terdiri dari pemerintah dan DPR RI telah menyepakati untuk menghapus syarat muslim sebagai wakif. Hal tersebut dilakukan untuk menghindari hal yang paradoks, karena dalam sejarah Islam dan hadis ditemukan bahwa wakaf yang diberikan oleh orang yang Non Muslim adalah benda yang sah, dengan makna bahwa wakaf tersebut diterima. Hanya saja ada catatan bahwa bahwa wakaf yang diberikan oleh wakif Non Muslim hendaknya diarahkan untuk hal-hal yang terkait dengan kemaslahatan umat bukan diperuntukkan untuk tempat-tempat ibadah. ${ }^{27}$

Setelah lahirnya Undang-undang Nomor 41 Tahun 2004 Tentang Wakaf, pemerintah (Departemen Agama) melakukan berbagai upaya dalam rangka mendorong dan menfasilitasi agar pengelolaan Wakaf dapat dilakukan secara profesional, amanah, dan transparan sehingga tujuan pengelolaan Wakaf dapat tercapai. Untuk itu, sebagai langkah kongkrit Departemen Agama dalam merespon kebutuhan tersebut, dibentuklah Direktorat Pemberdayaan Wakaf yang berada di bawah naungan Direktorat Jenderal Bimbingan Masyarakat Islam. Dengan lahirnya Direktorat Pemberdayaan Wakaf yang terpisah dari Direktorat Pemberdayaan Zakat merupakan bentuk kesungguhan pemerintah dalam mendorong dan menfasilitasi bagi pemberdayaan Wakaf secara lebih baik.

Berdasarkan uraian di atas, dengan telah diaturnya Wakaf dalam bentuk undang-undang di Indonesia, sektor Wakaf dapat lebih difungsikan ke arah peningkatan kesejahteraan sosial ekonomi umat. Dari sini nampak jelas bagaimana kepentingan kesejahteraan sosial sangat kuat mempengaruhi proses regulasi di bidang perwakafan. Semangat pemberdayaan potensi Wakaf secara produktif dan profesional yang dikumadangkan undang-undang Wakaf adalah untuk kepentingan kesejahteraan

${ }^{27}$ Muhammad Sesse Sudirman. 2010 “Wakaf dalam Persfektif Fikih Dan Hukum Nasional”, dalam Jurnal Hukum Diktum, Vol 8/ Nomor 2, Juli 2010 STAIN (Sekolah Tinggi Agama Islam Negeri) Parepare, h.152. 
umat manusia di bidang ekonomi, pendidikan, kesehatan, maupun bidang sosial keagamaan lainnya. Seruan ini mendorong munculnya lembaga pengelola Wakaf uang yang dilakukan oleh perusahaan investasi, bank syariah, dan lembaga investasi syariah lainnya.

\section{Kedudukan Dan Kewenangan Badan Wakaf Indonesia}

\section{a. Kedudukan Badan Wakaf Indonesia}

Kedudukan Badan Wakaf Indonesia, dalam Undang-Undang Wakaf Nomor 41 Tahun 2004 Pasal 48, ditetapkan bahwa Badan Wakaf Indonesia adalah lembaga yang berkedudukan sebagai media untuk memajukan dan mengembangkan perwakafan nasional. BWI berkedudukan di ibukota Negara Kesatuan Republik Indonesia dan dapat membentuk perwakilan di Provinsi dan/atau Kabupaten/Kota sesuai dengan kebutuhan. Dalam kepengurusan, BWI terdiri atas Badan Pelaksana dan Dewan Pertimbangan, masing-masing dipimpin oleh satu orang Ketua dan dua orang Wakil Ketua yang dipilih dari dan oleh para anggota. Badan pelaksana merupakan unsur pelaksana tugas, sedangkan Dewan Pertimbangan adalah unsur pengawas pelaksanaan tugas BWI. Jumlah anggota Badan Wakaf Indonesia terdiri dari paling sedikit 20 (dua puluh) orang dan paling banyak 30 (tiga puluh) orang yang berasal dari unsur masyarakat (Pasal 47-53, UU No.41/2004).

\section{b. Kewenangan Badan Wakaf Indonesia}

BWI Provinsi mempunyai tugas dan wewenang sebagai berikut:

1) Melaksanakan kebijakan dan tugas-tugas BWI di tingkat nasional.

2) Melakukan koordinasi dengan Kantor Wilayah Kementerian Agama dan lembaga terkait dalam pelaksanaan tugas.

3) Membina nazhir dalam mengelola dan mengembangkan harta benda Wakaf.

4) Bertindak dan bertanggung jawab untuk dan atas nama Perwakilan BWI Provinsi, baik ke dalam maupun ke luar.

5) Memberhentikan dan/atau mengganti nazhir tanah Wakaf yang luasnya 1.000 meter persegi sampai dengan 20.000 meter persegi.

6) Menerbitkan tanda bukti pendaftaran nazhir Wakaf tanah yang luasnya 1.000 meter persegi sampai dengan 20.000 meter persegi.

7) Melakukan survei atas tanah Wakaf yang luasnya paling sedikit 1.000 meter persegi yang diusulkan untuk diubah peruntukannya atau ditukar dan melaporkan hasilnya kepada BWI.

\section{c. Divisi Program Kerja Badan Wakaf Indonesia}

Berdasarkan data dari Departemen Agama RI Tahun 2008, di Indonesia terdapat tanah Wakaf sebanyak 3666.595 lokasi, lokasi tanah Wakaf tersebut pada umumnya tidak strategis secara ekonomis, dikarenakan lokasinya jauh dari pusat 
ekonomi, atau kondisi tanahnya tidak subur, atau karena topografinya. Tanah-tanah Wakaf yang strategis dan yang tidak strategis secara ekonomis ini akan dipetakan, untuk selanjutnya akan ditetapkan pola pengelolaannya untuk tujuan produktif. Pemetaan tanah Wakaf ini akan dilakukan dengan bersinergi bersama divisi-divisi lain yang terkait; Divisi Pengelolaan dan Pengembangan Wakaf; Divisi Pembinan Nazhir; Divisi Kelembagaan; Divisi Hubungan Masyarakat; Divisi Penelitian dan Pengembangan.

\section{d. Kerjasama Badan Wakaf Indonesia dengan pihak terkait}

Dalam mengemban amanah tersebut BWI perlu menjalin kerjasama dengan pihak-pihak terkait guna memajukan dan mengembangkan perwakafan di Indonesia. Dalam hal ini BWI telah menjalin kerjasama dengan lembaga-lembaga terkait, baik lembaga internasional maupun nasional. Di antara lembaga-lembaga yang telah bekerjasama dengan BWI dan dalam bidang apa kerjasama dilakukan yaitu: $\left.{ }^{28} 1\right)$. MoU dengan IDB (Islamic Development Bank). 2). Menjalin Kerjasama dengan Badan Waqaf Qatar dan Al-Amanah Al-Ammah Kuwait. 3). MoU dengan Kementrian Perumahan Rakyat dan Masyarakat Ekonomi Syariah. 4). MoU dengan Ikatan Ahli Ekonomi Islam Untuk Mengembangkan Perwakafan di Indonesia

\section{Peran Badan Wakaf Indonesia Terhadap Pelaksanaan Wakaf di Indonesia}

Berdirinya Badan Wakaf Indonesia berawal dari banyaknya tanah Wakaf dan inovasi pengembangan Wakaf yang belum terdata dan terkelola dengan baik, sehingga pendataan dan pembimbingan atas nazhir perlu diadakan sosialisasi dan pembinaan. Berdirinya Badan Wakaf Indonesia menjadi starting point untuk membangkitkan gerakan Wakaf. Dalam Pasal 47 ayat (1) Undang-Undang Tentang Wakaf disebutkan bahwa dalam rangka memajukan dan mengembangkan perwakafan nasional, dibentuk Badan Wakaf Indonesia. Salah satu tujuan perlunya dibentuk Badan Wakaf Indonesia adalah untuk memajukan dan mengembangkan perwakafan nasional. Dalam melaksanakan tugasnya Badan Wakaf Indonesia bersifat independen. Dilihat dari tugas dan wewenang Badan Wakaf Indonesia dalam undang-undang ini nampak bahwa Badan Wakaf Indonesia mempunyai tanggungjawab yang sangat berat, yakni mengembangkan perwakafan di Indonesia, sehingga nantinya Wakaf dapat berfungsi sebagaimana disyariatkannya Wakaf. Untuk itu orang-orang yang berada di BWI hendaknya memang orang-orang yang berkompeten di bidangnya masing-masing sesuai dengan yang dibutuhkan oleh badan tersebut. ${ }^{29}$

Dengan lahirnya Undang-undang Nomor 41 Tahun 2004 Tentang Wakaf dan Peraturan Pemerintah Nomor 42 Tahun 2006 Tentang Pelaksanaan Undang-undang Nomor 41 Tahun 2004 Tentang Wakaf, diharapkan perwakafan di Indonesia melalui

\footnotetext{
${ }^{28}$ Buku Pencangan Gerakan Wakaf Nasional Wakaf Uang oleh presiden Republik Indonesia, Di Istana Negara, Jum'at 8 Januari 2010, h.51-55.

${ }^{29}$ Dahlan, Abdul Aziz, et al (Ed.). 2016. Ensiklopedi Hukum Islam, Jilid 6, Cet. 1, Jakarta: Ichtiar Baru van, h.123.
} 
Badan Wakaf Indonesia dapat berkembang dengan baik sehingga dapat berfungsi untuk meningkatkan kesejahteraan masyarakat. Terdapat beberapa faktor yang menjadi hambatan utama nazhir dalam menjalankan pengelolaan tanah Wakaf pada masa kini, diantaranya: 1). Kurangnya sosialisasi pemahaman masyarakat terhadap Wakaf khususnya harta Wakaf tunai dan harta Wakaf produktif, beserta sistem pengelolaannya. 2). Nadhir masih banyak yang tradisional, pada umumnya masyarakat yang ingin mewakafkan hartanya, menyerahkan terhadap orang yang dianggap panutan dalam lingkup masyarakat tertentu, dan belum tentu yang diamanahkan mempunyai kemampuan yang baik dalam mengelola secara optimal. 3). Kurang memadainya peraturan perundang-undangan yang diterapkan di Indonesia tentang Wakaf.

Badan Wakaf Indonesia telah lahir sebagai jawaban bagi pengembangan pengelolaan perwakafan Indonesia dengan lebih profesional dan modern sehingga menghasilkan manfaat Wakaf yang dapat mensejahterakan umat. Sehingga kelak Badan Wakaf Indonesia akan menduduki peran yang sangat penting, selain berfungsi sebagai nazhir, juga sebagai pembina nazhir sehingga harta benda Wakaf dapat dikelola dan dikembangkan secara produktif.

Potensi Wakaf uang pada tahun 2007 untuk Indonesia nilainya sekitar tiga trilyun per tahun. Jumlah ini memang masih jauh bila dibandingkan dengan potensi zakat yang nilainya sekitar 21 trilyun menurut data PIRAC. Tetapi perbedaan yang sangat signifikan adalah bahwa dana Wakaf pokoknya akan tetap utuh dan semakin terakumulasi dari tahun ke tahun. Hal ini berbeda dengan dana zakat yang akan langsung habis dalam satu tahun. Tetapi angka tiga trilyun tersebut masih merupakan data yang terlalu muluk karena faktanya di lapangan, penghimpunan dana Wakaf uang di Indonesia masih sangat sedikit. Sebagai contoh Tabung Wakaf Indonesia yang dikonsentrasikan untuk penghimpunan dan pengelolaan Wakaf uang baru mampu mengumpulkan dana Wakaf uang sekitar dua milyar per tahun.

Oleh karena itu Badan Wakaf Indonesia ke depan tidak hanya berfungsi sebagai lembaga yang mengelola Wakaf secara independen dan mandiri agar dana yang dikelola lebih produktif, akan tetapi fungsi penyadaran dan sosialisasi terhadap masalah Wakaf, baik fungsi dan manfaatnya kepada masyarakat harus juga dimainkan perannya oleh Badan Wakaf Indonesia itu sendiri. Selama ini memang efektifitas untuk memberdayakan Wakaf dan juga menarik dana Wakaf dari masyarakat untuk dikelola oleh lembaga Wakaf belum maksimal. Hal ini karena realisasi pencapaian di lapangan dengan potensi Wakaf di masyarakat sendiri belum berbanding lurus dan mencapai suatu titik yang sangat ideal.

Jika menengok keberhasilan dari negara Bangladesh dalam pengelolaan Wakaf tunai dengan dilakukannya sosialisasi pengenalan Sertifikat Wakaf Tunai, ternyata dapat mengubah kebiasaan dan pemahaman lama di tengah-tengah masyarakat Bangladesh, di mana biasanya orang yang berwakaf diidentikkan hanya melibatkan orang-orang kaya saja. Dengan adanya Sertifikat Wakaf Tunai yang dikeluarkan oleh Social Investment Bank Limited (SIBL) memang dibuat dengan nilai yang dapat dijangkau oleh mayoritas masyarakat Islam. Pola seperti ini menjadikan 
ibadah Wakaf bukan hanya didominasi orang-orang kaya, tetapi juga dapat diamalkan oleh orang banyak sesuai keadaan keuangan masing-masing. Selain itu pola seperti ini lebih mudah untuk diamalkan, karena tidak memerlukan proses administrasi yang rumit. ${ }^{30}$

Badan Wakaf Indonesia sebenarnya mempunyai fungsi sangat strategis dalam membantu, baik dalam pembiayaan, pembinaan maupun pengawasan terhadap para nazhir untuk dapat melakukan pengelolaan Wakaf secara lebih produktif. Pola organisasi dan kelembagaan Badan Wakaf Indonesia harus mampu merespon persoalan-persoalan yang dihadapi oleh masyarakat pada umumnya dan umat Islam pada khususnya. Ditingkat masyarakat, persoalan yang paling mendasar adalah kemiskinan, baik dalam arti khsusus, yaitu seperti yang dicerminkan dengan tingkat pendapatan masyarakat, maupun dalan arti luas, yang mencakup aspek kesehatan, pendidikan atau pemenuhan hak-hak asasi pada umumnya.

Keragaman budaya lokal yang sangat dinamis dan suku bangsa yang banyak di negara kita menjadi permasalahan sekaligus potensi tersendiri bagi Badan Wakaf Indonesia dalam menghimpun dan mengelola dana masyarakat secara luas. Jika pendekatan yang dilakukan kepada masyarakat dilakukan sesuai dengan budaya lokal yang ada dimasyarakat, bukan tidak mungkin efektifitas penghimpunan dana dan pengelolaan dana akan tercipta dan lebih efektif. Selain itu, Badan Wakaf Indonesia juga bertanggung jawab dalam membina nazhir agar menjadi lebih profesional dengan menyelenggarakan sejumlah pelatihan pengelolaan harta Wakaf, menerbitkan bukubuku Wakaf dan lainnya. Apalagi, pengembangan Wakaf kini didukung oleh UU No. 41 tahun 2004 tentang Wakaf dan Peraturan Pemerintah (PP) No. 42 Tahun 2006 tentang pelaksanaan UU No 41 tersebut, maka tidak ada alasan lagi bila pengelolaan dan pengembangan harta Wakaf di Indonesia tertinggal dengan negara-negara lain di dunia. Mestinya, Indonesia sebagai negara dengan jumlah penduduk muslim terbesar di dunia menjadi pionir dalam pengembangan ekonomi umat. ${ }^{31}$

Era otonomi daerah yang semakin menguat, potensi pengembangan Wakaf juga semakin besar jika disinergikan dengan peraturan dan keinginan daerah. Tentunya hal ini akan menjadi hal yang menarik karena otonomi daerah sangat memberikan peluang bagi pengembangan dan pemberdayaan pengelolaan Wakaf itu sendiri. Pola pengembangan organisasi Badan Wakaf Indonesia sendiri sudah harus mulai berorientasi kepada daerah dengan menyiapkan sumber daya manusia nazhir di daerah agar lebih profesional. Fungsi-fungsi yang melekat di tubuh Badan Wakaf Indonesia seperti fungsi motivator, fungsi fasilitator, fungsi regulator, fungsi eduation, dan fungsi pendukung lainnya harus selaras dan tidak over lapping dalam implementasinya. Diperlukan sistem organisasi yang tanggap dengan tantangan zaman dan perubahan yang dinamis di masyarakat dalam mengefektifkan Wakaf sebagai alternatif sumberdaya untuk penciptaan kesejahteraan sosial masyarakat.

\footnotetext{
30 "Peran BWI Dalam Mengembangkan Wakaf Indonesia", dikutip http://www.islamic-world.net 15 Oktober 2019.

31 "Aset Wakaf, Sangat Besar tapi Belum Produktif", dikutip dari www.bw-indonesia.net 15 Oktober 2019.
} 
Jika dicermati lebih dalam selama ini masih banyak sumber daya daerah yang belum dikelola dengan baik. Jika masing-masing daerah yang memiliki sumber daya yang cukup memadai, bukan tidak mungkin bahwa lembaga perwakafan dibentuk melalui peraturan daerah dan khusus mengatur tentang kemungkinan dan kelayakan Wakaf, baik yang menyangkut Wakaf konvensional, Wakaf uang, dan bentuk Wakaf lain. Sehingga persoalan Wakaf tidak lagi menjadi otoritas pemerintah pusat atau lembaga tertentu yang ditunjuk pemerintah pusat, melainkan juga menjadi program produktif masing-masing daerah yang akan membawa kemaslahatan bersama bagi masyarakat daerah juga. Untuk menjalankan semua rencana praktis diatas, maka peran Badan Wakaf Indonesia sebagai lembaga pengelola harta khususnya dana tunai Wakaf nasional memerlukan sumber daya manusia yang baik sesuai dengan organisasi dan kecakapan ilmu yang dimiliki dengan tugas dan tanggung jawabnya. ${ }^{32}$

Peningkatan kualitas SDM pengelola Wakaf seperti nazhir diperlukan karena sudah menjadi sebuah rahasia umum bahwa lembaga keummatan selalu identik dengan ketidakprofesionalan, sehingga lembaga keummatan termasuk lembaga Wakaf bukan menjadi pilihan awal tenaga kerja nomor satu. Lembaga ini selalu menjadi pilihan nomor dua atau bahkan pilihan akhir ketika tidak ada perusahaan atau lembaga lain yang menampungnya. Lebih parahnya adalah menjadi tempat pembuangan sumber daya manusia yang sudah tidak produktif. Sehingga tidak salah apabila kinerja lembaga keummatan termasuk Wakaf tidak dapat tumbuh secara cepat, baik tumbuh dalam penghimpunannya maupun pengelolaannya. Dan menjadi tugas bersama untuk meningkatkan kualitas lembaga Wakaf ini, sehingga nantinya tidak terdengar ada asset Wakaf yang tidak dikelola, atau terdapat asset Wakaf yang hilang, diperebutkan dan lain sebagainya.

Dalam hal pendanaan, sumber pembiayaan Badan Wakaf Indonesia masih di bawah alokasi Kementerian Agama Republik Indonesia. Pengalokasian dana tersebut, kontradiksi dengan Pasal 47 ayat (2) Undang-Undang Wakaf yang menyatakan bahwa BWI merupakan lembaga independen. Di samping itu tantangan Badan Wakaf Indonesia dan peluang yang ada pada saat ini, adalah seperti pendanaan yang berimplikasi pada program yang tidak dapat berjalan, dan masyarakat pada saat ini masih kurang sosialisasi. Jika masyarakat telah mempelajari jelas tentang Wakaf, maka itu juga dapat digunakan untuk kebutuhan sosial. Untuk mengembangkan asetaset Wakaf yang tersebar di Indonesia belum adanya kerjasama antar lembaga pemerintah dan masyarakat dengan Badan Wakaf Indonesia yang saat ini memberikan solusi cerdas untuk menggunakan Wakaf, agar Wakaf lebih produktif, misalnya: DPR mendapatkan dana dari APBN yang besar dan dana APBN ini dapat digunakan untuk program sertifikasi Wakaf seperti Bantuan Seribu Titik Tanah Wakaf. Dan dananya diberikan dari Badan Pemberdayaan Masyarakat, bekerjasama dengan BAPENAS dan setelah itu dirancang program pembangunannya. ${ }^{33}$

\footnotetext{
32 "Peran BWI Dalam Mengembangkan Wakaf Indonesia", dikutip dari http://sigitsoebroto.blogspot.com/2009/06/peran-bwi-dalam-mengembangkan-Wakaf.html 15 Oktober 2019.

33 Tim Depag, 2008. Strategi Pengembangan Wakaf Tunai Di Indonesia, Jakarta: Direktorat Pemberdayaan Wakaf, h.113.
} 
Dari penjelasan di atas dapat disimpulkan bahawa Peran Negara dalam pengelolaan Wakaf menurut Undang-Undang Nomor 41 Tahun 2004 Tentang Wakaf menjelaskan bahwa, peran pemerintah (regulator, operator, pengawas) dalam hal mengurus Wakaf justru dirasakan sebagai kebutuhan hukum dalam masyarakat. Peran Negara memberikan hak penuh kepada lembaga pengelolaa Wakaf dalam hal ini peran Negara menujuk Badan Wakaf Indonesia sebagai lembaga pengelola Wakaf. Dalam rangka meningkatkan daya guna, Wakaf harus dikelola secara melembaga sesuai dengan syariat Islam, amanah, kemanfaatan, keadilan, kepastian hukum, terintegrasi, dan akuntabilitas sehingga dapat meningkatkan efektivitas dan efisiensi pelaksanaan dalam pengelolaan zakat. Pengaturan kelembagaan Badan Wakaf Indonesia dalam Undang-Undang Wakaf ini bukan hanya terhadap pengelolaan Wakaf, tetapi juga terhadap sistem ketatanegaraan Indonesia secara umum. Bentuk kelembagaan Badan Wakaf Indonesia yang mencampuradukkan antara lembaga nonstruktural dan lembaga pemerintah non kementerian, yang berimbas kepada penempatan lembaga mandiri di bawah Menteri akan menjadi persoalan ketatanegaraan tersendiri, atau bahkan menjadi hal yang buruk bagi pengaturan kelembagaan Negara di Indonesia.

\section{Analisis Penulis}

Wakaf memiliki perjalanan panjang dalam sejarah bangsa Indonesia, sebagaimana mengutip sejarah wakaf di beberapa daerah bahwa wakaf merupakan bentuk kebaikan hati yang secara nash juga hadist tidak ditemukan ayat-ayat yang mengatakan tentang hal tersebut demikian juga dengan hadist nabi tentang pelaksanaan wakaf. Namun demikian pelaksanaan wakaf dibeberapa negara adalah bentuk kerelaan dan keikhlasan seseorang untuk kebaikan bersama dan maslahat bersama.

Wakaf merupakan salah satu bentuk ijtihad yang digali dari 'urf tau adat istiadat yang berlaku di suatu bangsa. Wakaf memiliki banyak peraan, bahkan melalui wakaf program-program yang memiliki visi untuk memotong tali kebodohan atau kesenjangan ekonomi dapat diwujudkan, karena wakaf khair misalnya berfokus untuk memperbaiki taraf kehidupan secara umum.

Selanjutnya berbicara wakaf di Indonesia pun demikian, wakaf bukan barubaru saja setelah diterbitkan peraturannya, namun jauh sebelum bangsa Indonesia merdeka wakaf telah dilaksanakan sebagai bentuk hukum adat, yang secara histori kemudian diinventarisir oleh pemerintah Belanda terhadap aset-aset wakaf yang dimiliki oleh umat Islam sejak sebelum Masuknya Belanda.

Perjalanan panjang sejarah wakaf di Indonesia mencapai pada puncak diterbitkannya Undang-undang Nomor 41 Tahun 2004 tentang Wakaf yang mengakomodir bukan hanya sekedar masalah inventarisir benda-benda wakaf namun juga pengelolaan dan cara pelaksanaan Wakaf. Dengan terbitnya undang-undang wakaf, kini wakaf bertransformasi menjadi suatu lembaga yang memiliki kredibilitas juga profesional dalam mengurusi wakaf. 
Faktanya pelaksanaan wakaf sebelum adanya undang-undang tentang wakaf, membangun paradigma usang bagi masyarakat karena wakaf masih dipandang sebagi sebuah ibadah yang identik dengan julukan 3 M (makam, masjid dan madrasah), kurangnya literasi masyarakat menyebabkan wakaf masih dipandang sebelah mana. Padahal potensi wakaf di Indonesia sangat besar dan bisa menjadi alat untuk pemerataan ekonomi. Hal lain yang menjadi salah satu faktor penyebab lambatnya perkembangan wakaf adalah pandangan masyarakat terhadap wakaf yang cenderung terhadap penyaluran melalui aset-aset tidak bergerak (wakaf sosial). Padahal wakaf produktif atau wakaf uang sangat memiliki peran bukan hanya bermanfaat pada masyarakat, melainkan juga mengembangkan surplus investasi wakaf, misalnya saja yang telah dilakukan oleh lembaga-lembaga filantropi yang telah membangun pola wakaf dari bentuk konvensional menjadi wakaf produktif.

Berdasarkan data yang dirilis oleh BWI (Badan Wakaf Indonesia) potensi aset wakaf pertahun mencapai 2000 triliun dengan luas tanah wakaf mencapai 420.000 hektar, sementara potensi wakaf uang bisa menebus kisaran 188 Triliun pertahun, melalui undang-undang wakaf berikut juga lembaga pengelolaan wakaf maka pontensi wakaf bukan hanya akan berhasil dihimpun namun juga dapat diberdayakan dengan maksimal sehingga kemaslahatan umat, kesejahteraan umat akan tercapai.

Menurut analisis Penulis peran Badan Wakaf Indonesia pasca terbitnya Undang-Undang Nomor 41 Tahun 2004 Tentang Wakaf berdasarkan pada Pasal 47 ayat (1) tentang pembentukan Badan Wakaf Indonesia merupakan salah satu upaya untuk memberikan payung hukum yang diharapkan terhadap lembaga untuk meningkatkan profesionalisme dalam pengembangan Wakaf perwakafan di Indonesia meskipun dalam hal pengangkatan keanggotaan kepengurusan Badan Wakaf Indonesia perlu dihimbau dengan beberapa persyaratan diantaranya mempunyai visi dan misi komitmen yang tinggi untuk mengembangkan perwakafan, serta memiliki kemampuan pengetahuan dan pengalaman dalam mengelola aset Wakaf secara profesional dalam skala nasional. Melihat perkembangan dan pengelolaan Wakaf di beberapa negara yang telah berkembang maju sudah saatnya Badan Wakaf Indonesia melakukan upaya dan terobosan baru guna menggiatkan perwakafan di Indonesia, khususnya perannya sebagai nazhir.

Penulis memahami adanya pandangan masyarakat terhadap pemberlakuan Wakaf tunai berlawanan dengan persepsi umat Islam yang mengenal bahwa Wakaf itu berbentuk benda-benda tak bergerak. Kini menjadi persoalan beberapa masalah yaitu mengenai pengelolaan Wakaf uang, sementara pengaturan mengenai benda bergerak lainnya selain uang belum diakomodir sepenuhnya.

Setelah berlangsung 14 (empatbelas) tahun berlakunya Undang-Undang Wakaf Tahun 2004 Tentang Wakaf, perlu diadakan analisa dan kaji ulang sejauh mana efektivitas dan peranan Undang-Undang Wakaf bagi perkembangan Wakaf di tanah air, termasuk sejauh mana peranan Badan Wakaf Indonesia itu sendiri. Dalam perkembangannya hadirnya Badan Wakaf Indonesia belum berjalan secara maksimal dalam mengembangkan perwakafan di tanah air. Lembaga ini perlu mengembangkan 
aset-aset Wakaf melalui manajemen bisnis yang profesional dengan membentuk badan khusus yang berpola manajemen fundraising yang profesional.

Materi muatan undang-undang tentang pengelolaan Wakaf seharusnya didasarkan pada kebutuhan untuk menciptakan Wakaf dalam tata kelola yang baik (good governance) dalam pengelolaan Wakaf. Pengelolaan Wakaf saat ini menunjukkan adanya kelemahan dalam aspek pertanggungjawaban publik, akuntabilitas, transparansi, dan penataan kelembagaan dengan gambaran antara lain:

1. Belum adanya institusi pemerintah atau lembaga masyarakat, baik aktif maupun pasif yang mengatur secara tegas dalam memberikan jaminan Wakaf atau ahli warisnya berhak untuk melakukan pengawasan dan meminta pertanggungjawaban nazhir dalam pengelolaan Wakaf uang.

2. Belum ada institusi atau lembaga yang membuat kebijakan operasional untuk organisasi pengelolaan Wakaf sehingga sampai saat ini tidak ada standar sesuai yang diperlukan sebuah lembaga pengelola keuangan.

3. Terkait undang-undang Wakaf saat ini masih sekedar memberikan landasan hukum Wakaf uang, namun belum mendorong secara penuh bagi nazhir itu sendiri untuk mengembangkan dan mengelola Wakaf. Untuk itu perlu adanya pembenahan lebih lanjut bagi aturan Wakaf ke depan dalam hal upaya pengembangan nazhir yang profesional secara menyeluruh.

\section{KESIMPULAN}

Peran Badan Wakaf Indonesia memiliki tempat dan peran yang sangat strategis dalam merubah tata kelola Wakaf yang telah lama dilaksanakan dengan cara tradisional dan apa adanya. Badan Wakaf Indonesia bukan saja menjadi lembaga resmi yang memiliki kewenangan dalam melakukan pengurusan Wakaf, namun juga menjadi satu-satunya lembaga penegak hukum dalam mengatur dan mengelola Wakaf masyarakat Indonesia. Salah sat peranan yang sangat nampak adalah Badan Wakaf Indonesia telah menjadi fasilitator masyarakat, menjadi motivator terhadap para Wakif, juga menjadi regulator terhadap standart operasional pelaksanaan Wakaf di Indonesia. Badan Wakaf Indonesia adalah lembaga Independen, namun di dalam melaksanakan tugasnya Badan Wakaf Indonesia membangun pola pengendalian diantara Kementerian Agama, Badan Pertanahan Nasional juga Lembaga Keuangan Syariah.

Sistem pengelolaan Wakaf sebelum adanya Undang-Undang Nomor 41 Tahun 2004 terjadi banyak sekali mal administrasi terkait pencatatan tanah dan barang Wakaf mengingat pelaksanaannya masih tradisional. Namun kemudian dengan berlakunya Undang-undang Nomor 41 Tahun 2004 merubah tata kelola Wakaf leih profesional, bahkan perbuatan hukum dalam bentuk pencatatan Wakaf adalah wajib, sehingga memberikan perlindungan dan kepastian hukum bagi Wakif, Nadhir dan harta yang diwakafkan. 


\section{REFERENSI:}

Abdul Mannan, Muhammad, The Institution of Waqf: Its Religius and Socio-Economic Roles and Implications dalam Management and Developmen of Awqaf Properties, Proceeding of the Seminar, Jeddah: Islamic Research and Training Institute, Islamic Developmen Bank, 1987

Abu Zahrah, Muhammad, Ushul al-Figh. Kairo: Dar al-Fikr al-Arabi, t. th.

Achmad Sanusi ( 1994 ), Pengantar Ilmu Hukum dan Pengantar Tata Hukum Indonesia, Bandung, Tarsito.

Al-Alabij, Adijani. 2002. Perwakafan Tanah di Indonesia Dalam Teori dan Pratek. Jakarta: Raja Grafindo Persada.

Al-Asnawi, Jalaluddin Abd. Al-Rahim. Nihayah al-Wushul Syarh Minhaj al-Wushul, Jilid I, Kairo: Muhammad Ali Subaih, t. th.

Al-Bukhari, Abi Abdillah Muhammad bin Ismail al-Bukhari. Shahih Bukhari. Semarang: Toha Putera Dahlan, Abd. Rahman. 2010. Ilmu Ushul Figh. Jakarta: Amzah,

Al-Jamal, Ahmad Muhammad Abd al-Azhīm. 2007. al-Waqf al-Islâmī fi at-Tanmiyah alIqtishâdiyyah alMu'ashirah

Al-Maqdisi, Abu Muhammad 'Abd Allah Ibn Ahmad Ibn Ahmad Ibn Muhammad Ibn Qodamah. Al-Mughni Al-Syarah Al-Kabir. Beirut: Daar Al-Kutub Al-'Ilmiyah

Antonio, Muhammad Syafi'i. 2007. Waqaf dan Anggaran Pendidikan Umat. Jakarta: Gema Insani.

Aravik, Havis; Yunus, Nur Rohim; Sulastyawati, Dwi. 2019. Legal Politics of WaqfRegulation In Indonesia. Nur El-Islam; Jurnal Pendidikan dan Sosial Keagamaan. Volume 6, No. 1 (2019)

Astuti, Dewi. 2012. Kamus Popular Istilah Islam. Jakarta: PT. Gramedia

Athoillah, 2014. Hukum Wakaf. Bandung: Yrama Widya.

Azhar, Ahmad Basyir. 1977. Hukum Islam tentang Wakaf, Ijarah dan Syirkah. Bandung: Al Maarif.

Buku Pencangan Gerakan Wakaf Nasional Wakaf Uang oleh presiden Republik Indonesia, Di Istana Negara, Jum'at 8 Januari 2010.

Dahlan, Abdul Aziz, et al (Ed.). Ensiklopedi Hukum Islam, Jilid 6, Cet. 1, Jakarta: Ichtiar Baru van

Daud, Muhamad Ali. 1998. Sistem Ekonomi Islam Zakat dan Wakaf. Jakarta: UI Press.

Departemen Agama RI, 2005. Al-Qur"an dan Terjemahan. Bandung: CV. Diponegoro.

Departemen Agama RI, 2009. Al-Qur'an dan Terjemahnya, Jakarta: PT. Sigma Examedia Arkaleema.

Djatmika, Rachmat, 1983. Pandangan Islam tentang Infaq, Shadaqah, Zakat dan Wakaf sebagai Komponen dalam Pembangunan. Jakarta: Pustaka Panjimas.

Djunaidi, Achmad; dan Thobieb Al-Asyhar. 2008. Menuju Era Wakaf Produktif. Jakarta: Mumtaz Publishing. 
Duverger, Mavrice. 2010. Sosiologi Politik. Jakarta: Raja Grafindo Persada Haroen, Nasrun. 1997. Ushul Figh. Cet. 2, Jakarta: Logos Wacana Ilmu.

Faizal, A. Haq \& H.A. Saiful Anam.1993. Hukum Wakaf dan Perwakafan di Indonesia. Pasuruan: Garoeda Buana Indah

Ghofar, Abdul Anshori. 2005. Hukum dan Praktik Perwakafan Di Indonesia. Yogyakarta: Pilar Media.

Halim, Abdul. 2005. Hukum Perwakafan di Indonesia. Jakarta: Ciputat Pres.

Hasyim Kamali, Muhammad. Prinsip dan Teori-teori Hukum Islam, (Ushul Fiqh), alih bahasa

Huda, N. 2005. Hukum Tata Negara Indonesia. Jakarta: Raja Grafindo.

Ibrahim, Johni. 2007. Teori dan Metodologi Penelitian Hukum Normatif. Malang: Bayumedia Publishng.

Khallaf, Abd. Wahab. 2003. 'Ilmu Ushûl al-Fîgh, Kairo: Dar al-Hadits.

Khosyiah, Siah. 2010. Wakaf dan Hibah: Perspektif Ulama Fikih dan Perkembangannya di Indonesia. Bandung: Pustaka Setia.

M. Zein, Satria Efendi. 2005. Ushul Figh, Cet. 1, Jakarta: Kencana.

Nasution, Harun \& TIM Syarif Hidayatullah. 1992. Ensiklopedia Islam. Jakarta: Djambatan.

Noorhadi, 1996. Ushul Fiqh : Menuju Ijtihad Kontekstual, Yogyakarta: Fakultas Syari'ah Press

Notosusanto, Peradilan Agama Islam di Djawa dan Madura, (Yogyakarta: Tnp., 1953), h. 77

Qahaf, Mundzir. 2007. Manajemen Wakaf Produktif. Jakarta: Khalifa.

Rachmat, Naziroeddin. 1994. Harta Wakaf, Pengertian dan Perkembangan dan Sejarahnya di dalam Masyarakat Islam Dulu dan Sekarang. Jakarta: Bulan Bintang.

Rahardjo, Satjipto. 1986. Hukum dan Masyarakat. Bandung: Angkasa.

Soekanto, Soerjono, Mamudji Sri. Penelitian Hukum Normatif (Suatu Tinjauan Singkat). Jakarta: Rajawali Press.

Sokamto, Soejono. 2006. Sosiologi Suatu Penganta. Jakarta: Raja Grapindo Persada.

Suhadi, Imam, 2002. Wakaf Untuk Kesejahteraan Umat. Yogyakarta: Dana Bhakti Prima Yasa.

Sukanto, 1981, Meninjau Hukum Adat Indonesia Suatu Pengantar untuk mempelajari Hukum Adat, Jakarta: Rajawali Press.

Sya'ban, Zakkiyal-Din, 1964. Ushul al-Figh al-Islamy, Mesir: Dar al-Ta'lif.

Syafe'i, Rachmat, 2007. Ilmu Ushul Fiqih, Cet. III, Bandung: Pustaka Setia.

Syarifudin, Amir. 2004. Ushul Figh. Jakarta: Zikrul Hakim

Tim Depag, 2006. Pedoman Pengelolaan dan Pengembangan Wakaf. Jakarta: Bimas Islam.

Tim Depag, 2008. Panduan Pemberdayaan Tanah Wakaf Produktif Strategi. Jakarta: Bimas Islam.

Tim Depag, 2008. Paradigma Wakaf Produktif. Jakarta: Bimas Islam. 
Tim Depag, 2008. Strategi Pengembangan Wakaf Tunai Di Indonesia, Jakarta: Direktorat Pemberdayaan Wakaf

Tim Depag, 2009. Pedoman Pengelolaan Wakaf Tunai. Jakarta: Bimas Islam.

Usman, Rachmadi. 2009. Hukum Perwakafan di Indonesia. Jakarta: Sinar Grafika.

Usman, Suparman. 1999. Hukum Perwakafan di Indonesia. Jakarta: Darul Ulum Press.

\section{Skripsi dan Jurnal}

Fithriyah, Data Imro'atul. 2013. “Peran Badan Wakaf Indonesia Dalam Pengembangan Wakaf Uang Di Indonesia (Konsep dan Praktik Ditinjau dari Undang-Undang Nomor 41 Tahun 2004 tentangWakaf) "Malang, UIN Maulana Malik Ibrahim.

Huda, Miftahul. "Manajemen Fundraising Wakaf : Potret Yayasan Badan Wakaf Universitas Islam Indonesia Yogyakarta dalam Menggalang Wakaf", dalam Jurnal Justitia Islamica,Vol. 11/ No. 1, Januari-Juni 2014.

Sudirman, Muhammad Sesse, "Wakaf dalam Persfektif Fikih Dan Hukum Nasional", dalam Jurnal Hukum Diktum, Vol 8/ Nomor 2, Juli 2010 STAIN (Sekolah Tinggi Agama Islam Negeri) Parepare.

\section{Peraturan Perundang-undangan}

Negara Republik Indonesia, Undang-Undang Nomor 41 Tahun 2004 Tentang Wakaf.

Negara Republik Indonesia, Undang-Undang Nomor 42 Tahun 2006 tentang pelaksanaan Nomor 41 Undang-Undang Nomor 41 Tahun 2004 Tentang Wakaf.

\section{Internet dan Media Masa}

Aset Wakaf, Sangat Besar tapi Belum Produktif, Artikel ini telah dimuat di Republika, Selasa, 8 Juli 2008

Dian Masyita, Muhammad Tasrif, dan Abdi Suryadinata Telaga, "A Dynamic Model for Cash Waqf Management as One of The Alternative Instruments for the Poverty Alleviation in Indonesia," hal. 1 diakses dari http://www.islamicworld.net

Prianto, Sigit Indra, 2009. Peran BWI Dalam Mengembangkan Wakaf Indonesia.

http://www.tabungWakaf.com. [15 Oktober 201919.45 WIB]

www.bw-indonesia.net [15 Oktober 201919.45 WIB]

http://sigitsoebroto.blogspot.com/2009/06/peran-bwi-dalam-mengembangkan-Wakaf.html. Oktober 201919.45 WIB]

http://journaluinjkt.ac.id/index.php/esensi "Analisis Kelembagaan Badan Wakaf Indonesia", Jurnal Bisnis dan Manajemen, III, (2016), h.119, Akses pada tanggal 2 November $2019,23: 45$

file://localhost/D:/mine/33-sejarah-dan-perkembangan-Wakaf-.html,. Akses pada tanggal 12 Juni 2012, di tulis oleh sokaraja Selasa, 15 Pebruari 2011 21:42) 